met the steamers Nordenskjöld, Obe, and Louise, the last named of which the expedition went on board. Outside Yugor Schar the Louise lost her propeller, and had to be taken in tow to Yammerfest by the Nordenskjöld. On August 30 we landed at Vardö.

THE leading paper in Heft ix. of Petermann's Geographische Mittheilungen accompanies a map of the two principal, almost exclusive, nationalities of Bohemia, the Germans and the Czechs. At the last census of Austria-Hungary, on December 3I, I880, the Czechs in Bohemia amounted to $3,470,252$, the Germans to $2,054,174$; in all, $5,524,426$. Unfortunately the column of the census paper designed for the specifications of the nationality of each inhabitant was headed "Umgangssprache" (literally, the language of ordinary intercourse), a word by no means best calculated to educe in any case the national leaning of the person filling it up. On comparing this last census with former ones, it appears that the German and Czech elements maintain about the same numerical relation to each other in Bohemia as they had continued to do throughout the three previous decades. Their present proportions are thirty-seven Germans to sixty-three Czechs. The Czechs are in strongest force in the centre, while the surrounding provinces, especially those of the north-west, are chiefly occupied by the Germans. Local fluctu itions in the relative proportions of the two nationalities occur principally in the districts where the two are most mixed or where they border oa each other in industrial, manufacturing, and mining, especially extensive coal-mining districts, and in places in which there has been a rapid increase of population. In almost none of these cases, however, has the former character of any quarter been changed. It is observable that the Germans in predominatingly Czech districts generally cohere in isolated communiti 25 , whereas the Czechs in corresponding cases are disposed to assimilate to the preponderating foreign element. In proportions ranging as low as from one per cent. to one per thousand, Germans are to be found everywhere throughout Bohemia, ex cept in the district of Blatna, where they muster only 43 against 52,522 Czechs. Czechs, again, are tutally wanting in the Asch and Plau districts, and number less than one-thou sandth of the population respectively of Gabel, Graslitz, Schluckenau, and Teol. Elsewhere in proportions ranging from one-thousandth to one per cent. and upwards, they are diffused all over the kingdom. Other nationalities than those of German; and Czecbs are found in Bohemia in diminishingly small numbers: Pules reaching 1303 , Ruthenes 1285 , Italians $14 \mathrm{I}$, other nationalit.es falling short of the number of IOO. It is fu ther found that while Bohemians in foreign countries, chiefly in Western Austria and Germany, amount to 490,565 , the nu nber of foreigners in Bobemia is only 80,236 , drawn, too, chiefly from Western Austria and Germany.

DR. EMIN BEy, continuing his tour through the Madirië Rohl, gives a description of the country he traversed between Biti and Bufi, more particularly the river Lau or Doghúrguru, as, along with other names, it is variously called by the natives in various parts of its course. Rumbehk, the principal place of the Mudirië Rohl, and the Agahr, and other Dinka tribes are next described; then the country passed in traversing the province of Gohk as far as the Roah River, and back to Jalo; the Lri land and the Upper Jalo to Sajadihn, with the march back to Iado.

IN another article an interesting sketch is given regarding the progress of the cartography of the peninsula of Corea, accompanying whish is a map of the country bise 1 on the one published in 1875 by the Ministry of War at Tokio, and embracing all the latest tracings of the coast.

THE last volume (thirty-eighth) of the Memoirs of the Topographical Department of the Russian General Staff $\mathrm{c}$ nntains, be ides the usual reports on the geodetical and topographical operations in Russia, the following memoirs :-On the measurement of the base on a string during the trijonometrical survey of Bulgaria, by Col. Lebedeff; on the measurements of the pendulum made in India, by General Ste'snitsky; result; of levellin's made during the years $187 x$ to 1877 along Russian ralways, by Col. Tillo. It result; from these levellings, which were made with a very $g$ eat degree of accuracy, that the level of the Baltic Sea at Dunamunde is 2 ro feet lower than at Cronstadt. The possible error is $\pm 0^{\circ} 91$ feet.

M. LesSAR has written to the Russian Geographical S jciety from. Askabad, on Juae 16 , that he has explored the O.rgouz River, which was known only in its upper parts. Even the
Tekkes did not know the route to the east of Mirza-chile. The journey was very difficult. The bed of the Ongouz being very undefined, the expedition often lost its way. The kaks or cisterns were empty, as there was not a single strong rain in April. Still M. Lessar reached Kavakhly, and thence proceeded to Khiva, whence he returned to Askabad via Mirza-chile. When writing his letter he was ill, and unable to continue his journey.

\section{THE BRITISH ASSOCIATION}

\section{REPORTS}

Report of the Committee, consisting of Lieut.-Col. GodwinAusten, Dr. G. Hartlauh, Sir F. Hooker, Dr. Günther, Mr. Secbohm, and Mr. Sclater (Secretary), appointed for the purpose of investigating the Natural History of Socotra and the atjacent Highland' of Arabia and Somali Land.-Prof. Bayley Balfour's labours on the botanical collection made in Sucotra are nearly brought to a close, and the results will shortly be published in a volume of the Transactions of the Royal Society of Edinburgh. The value and completeness of this memoir will be much increased by the additional specimens subsequently obtained in Socotra by Dr. Schweinfurth, which have been lent to Prof. Balfour by the collector. The fresh-water shells collected by Prof. Balfour have been described by Lieut.-Col. GodwinAusten in a paper read before the Zoslogical Society of London in January last, and published in the first part of their Proceedings for the present year. The Diatomacex have been examined by Mr. Kilton of Norwich, and described in a paper which will be read before the Zoological Society of Lond on during their next session.

Report of the Committee, consisting of Sir Foseph Hooker, Dr. Gïnther, Mr. Howard Saunders, and Mr. P. L. Sclater (Sccretary), appointed for the purpose of Exploring Kilimanjaro and the adjoining Mountains of Eastern Equatorial Africa. - The Committee having been unsucces ful in obtaining the services of a condustor for this expedition, nothing has been done.

Report of the Conmittee, consisting of Mr. Fohn Cordeaux (Secretary), Mr. F. A. Harvie-Brown, Mr. P. M. C. Kermode, Prof. Nezuton, Mr. R. M. Barrington, and Mr. A. G. More, reappointed at Southampton for the purpose of obtaining (with the consent of the Master and Brethren of the Trinity House, and the Commissioners of Northern and Irish Lights) Observations on the Migration of Birds at Lishthouses and Lightships, anl of reporting on the same. - The General Report of the Committee, of which this is in fact an abstract, comprises the observations taken at lighthouses and light-vessels, and a few special land stations, on the east and west coasts of Englind and Scotland, the c jasts of Ireland, Isle of Man, Channel Islands, Orkney and Shetland Isles, the Hebrides, Faroes, Iceland, and Heli yol and, and one Baltic station-Stevns Fyr on Stevns Klint, Zealand, for which the Comnittee is indebted to Prof. Litken of Copenhagen. Altogether 196 stations have been supplied with schedules and printed instructions for registering observations, and returns have bien received from about 123a result which is very satisfactory, showing as it does the general interest taken in the work, and the ready cooperation given by the lightkeepers in a sisting the Committee.

As in preceding years, the line of autumn migration has been a broad stream from east to we st, or fro.n points south of east to north of west, and covering the whole of the east coast. In I 880 , to judge from the returned schedule;, a large proportion of the im nigrants came in at the more southern stations; in I88r they covered the whole of the east coast in tolerably equal proportions; but in 1882 the stati ns north of the Humber show a marked preponderance of arrivals. Altogether a vast migration took place this year upon our east coast, the heaviest waves breaking upon the mouth of the Humber, Flamborough Head, the Farne Islands, I ile of May at the entrance to the Firth of Forth, and again, after missing a long exteat of the Scotch coast, at the Pentland Skerries. The Bell Rock also came in for a share, although apparently a much snaller one than the Isle of May. The exsterly winds prevailed all along our east coasts, ge:nerally strong to gale;, and the succession of south.easterly and easterly gales in October, between the 8th and 23 rd, occurring as they did at the usual time of the principal mi yration, b-uught vast numbers of land birds to our shores. From the Farses in the north to the extreme south of England this is found to have been the case. 
Although migration--that is, direct migration-on out east coast, is shown :o have extended over a long period, commencing in July and continuing, with but slight intermissions, throughout the autumn and into the next year to the end of January, yet the main body of migrants appear to have reached the east coast in October, and of these a large pro ortion during the first fortnight in the month. From the 6th to the 8th inclusive, and again from the 12 th to the 15 th, there wac, night and day, an enormous rush, under circums ances of wind and weather which, observations have shown, are most unfavourable to a g ood passage. During these periods birds arrived in an txhausted condition, and we have reasons for concluding, from the many reported as alighting on fishing smacks and vessels in the North Sea, that the loss of life must have been very considerable. Large flights also are recorded as having appeared round the lanterns of lighthouses and light-vessels during the night migration. From the 6 th to the 9 th inclusive strong east winds blew over the North Sea, with fog and drizzling rain, and from the night of the I 2 th to I 7 th very similar weather prevailed. Mr. W. Littlewood, of the Galloper light:hip, forty miles south east of Orfordness, reports that, on the night of October 6 , larks, starlings, treeparrows, titmice, common wrens, redbreasts, chaffinches, and wlovers were picked up on the deck, and that it is calculated that from 500 to $6 \mathrm{co}$ struck the rigging and fell overboard: a large proportion of these were larks. Thou ands of birds were flying round the lantern from $\mathrm{I} x .30 \mathrm{p} . \mathrm{m}$. to $4.45 \mathrm{a} . \mathrm{m}$., their white hreasts, as they dashed to and fro in the circle of light having the appearance of a heavy snowstorm. This was repeated on the 8 th and 12 th, and on the night of the $13^{\text {th }} 160$ were picked up on deck, including larks, starling; thrushes, and two redbreasts. It was thought that ICOO struck and went overboard into the sea. It is only on dark, rainy nights, with snow or fog, that such casualties occur; when the nights are light, or any stars visible, the birds give the lanterns a wide berth.

Undoubtedly the principal feature of the autumn migration has been the extraorlinary abundance of the gold-crested wren. The flights appear to have covered not only the east coast of England, but to have extended southward to the Channel Islands and northward to the Faroes (see Report, East Coast of Scotland). On the east coast of England they are recorded at no less than twenty-one stations from the Farne Islands to the Hanois Lighthouse, Guernsey, and on the east coast of Scotland at the chief stations from the Isle of May to Sunburgh Head (at which latter station they have rarely been seen in previous years). Mr. Garrioch, writing from Lerwick, says: "In the evening of October 9 my attention was called to a large flock of birds crossing the harbour from the Island of Bressay, and on coming to a spot on the shore where a number had taken refuge from the storm, I found the flock to consist of gold-crests and a few fire-crests amongst them; the gold-crests spread over the entire Island, and were observed in considerable numbers till the middle of November." The earliest notice on the east coast is August 6 , the latest November 5 , or ninety-two days; they arrived somewhat sparingly in August and September, and in enormous numbers in October, more especially on the nights of October 7 and 12, at the latter date with the woodcock. This flight appears to have extended across England to the Irish coast, for on the night of the I 1 th a dozen struck the lantern of the Tuscar Rock Lighthouse, and on the night of the $13^{\text {th they }}$ were continually striking all night. During the autumn enormous numbers crossed Heligoland, more especially in October. On the night from the 28th to the 29th Mr. Gätke remarks: "We have had a perfect storm of gold-crests, perching on the ledges of the window-panes of the lighthouse, preening 'heir feathers in the glare of the lamps. On the 29 th all the island swarmed with them, filling the gardens and over all the cliff -hundreds of thousands. By 9 a.m. most of them had passed on again." Not less remarkable was the great three days' $\mathrm{fti}_{3}$, ht of the common jay, past and across Heligoland, on October 6, 7 , and 8. Thou ands on thousands, without interruption, passed on overhead, north and south of the island too, multitudes like a continual stream, all going east to west in a strong south-easterly gale. It would have been interesting if we had been able to correlate this migration of jays with any visible arrival on our English coast, but in none of th : returns is any mention made of jays. Subsequently we have received numerous notices of extra rdinary numbers seen during the winter in our English woodland:. Thi; seems especially to have teen the case south of a line drawn from Flamborough Head to Portland Bill in Dorset. Additions and unusual numbers were also observed at Arden on Loch Lomond side.
The returns show very clearly that the spring lines of migration followed by birds are the same as those in the autumn, but of course in the reverse direction-from west and north-west to east and south-east. Another point worth noting is the occurrence of many species in spring at the same stations frequented by the species in autumn. Thus double records occur at the Mull of Galloway, Bell Rock, Isle of May, as well as at some English stations.

As this is the fourth report issued by the Committee, we may perhaps, with the mass of facts at our disposal, be expected to draw deductions which, if they do not explain, may serve at least to throw some light on the causes influencing the migration of birds. We might reasonably reply that the work undertaken by us was not to theorise, or attempt explanations, but simply to collect facts and tabulate them ; this we have endeavoured to do, in the shortest and simplest manner consistent with accuracy of detail. There is, however, one circumstance which can scarcely fail to present itself to those who have gone carefully into the reports issued by the Committee, namely, the marvellous persistency with which, year by year, birds follow the same lines, or great highways of migration, when approaching or leaving our shores. The constancy of thes e periodical phenomena is suggestive of some settled law or principle governing the movement. It is clearly evident, from the facts already at our disposal, that there are two distinct migrations going forward at the same time, one the ordinary flow in the spring and ebb in the autumn across the whole of Europe. A great migratory wave moves to and from the nesting-quarters of the birds, in the coldest part of their range, north-east in the spring and south-west in the autumn. Quite independent of this there is a continual stream of immigrants, week by week and month by month, to the eastern shores of these islands, coming directly across Europe from east to west, or more commonly four points south of east to north of west, and the reverse in the spring. The e immigrants are mainly composed of those common and well-known species which annually make these islands their winter quarters, and, as a rule, take the place of our summer birds. They come in one broad stream, but denser on some special lines or highways than others. Cutting the Jine of ordinary migration at nearly right angle;, one flauk brushes the Orkney and Shetland Isles, pouring through the Pentland Firth, even touching the distant Faroes; the southern wing crosses the Channel Islands, shaping its course in a north-westerly direction to the English coast.

Ninth Report of the Committee for investigaling the Circulation of Underground Waters in the Permeable Formati ns of Eng. land, and the Quantity and Character of the Water supplied to various Touns and Districts from these Formations. Report drawn up by C. E. De Rance. - Ten years having elapsed since the Committee was appointed at Belfast, they think this a fitting opportunity to review the results so far obtained, and to point out where they consider additional information is still required, in the hope that they may receive assi-tance in their investigations from the various local societies or from individuals who may be disposed to aid in the work. The work intrusted to the Committee was twofold - first, to inquire into the circulation of underground waters in permeable formations; secondly, to ascertain the quantity and qua'ity of the water supplied to towns and districts from these formations. The information obtained occupies nine reports; the eight already published fill up no less than 163 pages of the annual volumes of the Association, and contain a record of upwards of 500 wells and borings. The Committee helieve that the publication of these results, by directing public opinion to the value of such supplies, and by the preservation of the records of those carried out, has given an impetus to water of this class being generally adopted for domestic consumption in districts where gravitation supplies are unsuitable or unattainable. As regards the first head of inquiry - the circulation of underground water-much remains to be learnt, especially as to the influence of variation of barometrical pressure on the volume of springs. Independent investigation is now being carried on by Mr. Baldwin Latham, but it is exceedingly desirable that numerous observations should be taken in different classes of rocks, the quantity of water a rock is capable of holding being no measure of the quantity of water it is capable of yielding. The difference of the period of time in which two rocks will absorb, and give off by gravity, the same quantity of water is governed by the difference of their chemical compoition. The chemical composition of two rocks being identical, their facility of discharge of water is in direct relation 
to the amount by which they are traversed by planes of joints and fissures, and the extent these may run parallel or at right angles to the valleys which cut into and expose the water-bearing beds. The proportion of the annual rainfall that is absorbed by different classes of rocks is a subject that requires further examination. The quantity is largely regulated by the quantity stored from frevious years. After a succession of dry years the permanent water-level is reduced to minimum figures, and the water gradient becomes nearly flat and springs cease to flow. The first heavy rains will be neariy wholly absorbed, until the maximum water-gradient is reached and the rocks are stored with the largest amount of water they can hold. After they are once charged, all excess of rainfall runs off in floods, and the amount absorbed is practically nil. Spread over the twelve months, the annual amount absorbed is probably never more than fifteen inches, and the average ranges from five inches in chalk countries to ten inches in new red sandstone areas. In millstone grit districts about eight inches are absorbed, but the permeable beds are thin, and the water is thrown off again in numerous springs, as a rule in the same drainage basin, giving permanence to the dry-weather flow of the streams traversing them. Except in waterworks drainage areas but few observations exist as to the actual volumes run of daily by the rivers of this country, and data on this subject are much required, as well as a permanent record of the height to which floods rise in the various river basins. Further observations are required as to the action of faults in acting as ducts, along the face of which water is constantly passing, and barriers separating districts into distinct drainage areas. The facts so far obtained point to faults traversing thick permeable sandstone and limestone, having their formations on both sides of the dislocation, as offering no obstacle to the free passage of waters, which, even if locally obstructed by the hardened face or slickenside jointing of the fault, invariably finds its way through crack; extending across the width of the fault to faults traversing thick shales and clays of any age. The fissure, be it wide or narrow, always appears to have been filled with the im. permeable material forming the sides, and in some cases, when porous rocks have been immediately overlaid by impermeable material since denuded, the fissure of the fault has been filled from above at a time when the fault had an upward prolongation, destroyed with the denuded material referred to. The daily registration of the heights of the streams might easily be made on gauges, painted on the county bridges, but the orsanisation necessary to carry this out is entirely beyond the scope of the British Association, and should be carried out at the national charge, being of the highest importance to the country. The determination of the number of cubic feet of water carried down at selected points on the English rivers, particularising whether it represents ary-zeather, average, or flood-fow, wonld be of very high value, and might well te undertaken by the Asiociation. Such observations, stating the run-off per square mile of drainage area and the geological character of the area drained, would have more than a local value. Permeable rocks below the permanent water-level of a district may be regarded as a reservoir of which the cubic content is limited by the size of the spaces between the grains, and the width of the fissures and cracks by which the rock may be traversed. The quantity of water such rocks are capable of storing has had much light thrown upon it by the investigations of Mr. Wethered, published in the fourth appendix to the eighth report.

Third Report of the Committee, consisting of Mr. Sclater, Mr. Howard Saunders, and Mr. Thiselton Dyer (Secretary), appointed for the puirpose of investigating the Natural History of Timor Laut. - In the month of January a box containing seventy birds' skins was received from Mr. Forbes, with the note, "This first instalment of birds is a rough selection, which, probably, may contain new species." The collection was examined by Mr. Sclater, who communicated an account of it to the meeting of the Zoological Society on February 20. The species were fifty-five in number, sixteen of which were described in the paper as new to science. "The general facies of the avifauna, as thus indicated, was stated to be decidedly Papuan, with a slight Timorese element, evidenced by the occurrence of certain species of Geocichla and Erythrura, while the new one (Strix sororcula) was apparently a diminutive form of a peculiar Australian species." About the same time the Committee received from $\mathrm{Mr}$. Forbes a detailed report of his proceedings in Timor Laut. This was an extremely interesting document, but dealt principally with ethnographical details. The Committee, therefore, decided that it should be communicated at once to the Anthropological Institute; and this Mr. John Evans, Treasurer of the Royal Society and VicePresident of the Institute, very kindly undertook to do. The paper was read at the meeting on March $I_{3}$, and has since been published in the Journal of the Institute. In February the bulk of Mr. Forbes's collections reached Kew in four cases. They contained an extremely complete ethnographical collection, a further collection of birds, a collection of twelve crania and specimens of human hair, and a miscellaneous zoological collection. The. Committee decided that a selection from the ethnographical collection should be handed to Mr. Franks, keeper of the Department of Ethnography in the British Museum; that the additional birds should be examined by Mr. Sclater, and that the miscellaneous zoological collections should be sent to the zoological department of the British Museum to be selected from, This was accordingly done. A series of the ethnographical specimens was sent to the meeting at the Anthropological Institute to illustrate the reading of Mr. Forbes's report, and a description of these, drawn up by Mr. C. H. Read, is printed as an appendix to the paper in the Journal of the Institute. Prof. Flower, who presided on the occasion, also stated that "the results of a cursory examination of the twelve crania which Mr. Forbes had collected were that eight were brachycephalic, and of decidedly Malay type; one was dolichocephalic, prognathous, and with large teeth, indicating Papuan or Melanesian affinities; and the other three were more or less intermediate. This is what might have been expected on the border-land of two distinct races; but the great preponderance of the first-named was very marked. Nearly all showed signs of artificial flattening of the occipital region. At the meeting $\mathrm{cf}$ the Zoological Society on April I 7, Mr. Sclater read a second paper on the additional birds collected by Mr. Forbes in the Tenimber group. "The avifauna of the group, as indicated by Mr. Forbes's collection contained fiftynine species, of which twenty-two were peculiar to these islands." At the meeting of the same Society on May I, Mr. W. F. Kirby reported on the small collection of Hymenoptera (five new species were described) and of Diptera sent home by Mr. Forbes. On June 5 a communication was read from $\mathrm{Mr}$. A. G. Butler, containing an account of twenty-three Lepidoptera. These comprised twenty-three species of Lepidoptera; the butterflies were well preserved, the moths in poor condition. Mr. Butler described ten new species. Deducting wide-ranging forms, the following is his analysis of the characteristic species:- "IndoMalayan, 2; Austro-Malayan, Io; Australian, 3. The only surpri-ing thing in this distribution is the preponderance of Timor over Aru or New Guinea forms; the species characteristic of that island being only equalled by those from Aru, New Guinea, and Amboyna combined." Mr. Boulenger also reported, at the same meeting, upon the reptiles and batrachians. Two new species were described-the one a lizard of the Australian genus Lophognathus, and the other a snake of the Indian genus Simotes. "The snake was of special interest, as no species of the genus Simotes had hitherto been previously known to occur eastward of Java."

Report of the Committee, consisting of General Pitt-Rivers, Dr. Beddoe, Mr. Brabrook, Prof. Flower, Mr. F. Galton, Dr. Garson, Mr. J. Park Harrison (Secretary), Dr. Muirhead, Mr. F. W. Rudler, and Prof. Thane, appointed for the purpose of Defining the Facial Characteristics of the Races and Principal Crosses in the British 1sles, and obtaining Illustrative Photographs.-Owing to the comparative scarcity of skulls and other remains of the earlier inhabitants of the British Islands, and the imperfect condition of many of them owing to lapse of time, more difficulty has been experienced in completing the identification of the Long-barrow type than occurred in the case of the Round-barrow and Saxon types (B and C), the features of which were defined in the Report of 1882 . There appears, however, to be little doubt that the short dark type, which, as the Conmittee mentioned last year, certainly exists in the population at the present time, and which offers a marked contrast to the other types, accords in stature, lightness of frame, narrowness of skull, and fine osseou; features generally, with the skeleton remains found in the majority of the early barrows. The Committee, therefore, have no difficulty in considering it as the main Type A ; and its characteristic features have consequently been inserted in the annexed table, for comparison with Types B and C. The question whether there was a second pre-Celtic race in this country is hardly ripe for discussion; but it is receiving the special attention of several members of the Committee. 
Talle in which the Typical Features of the Three Principal Races in the British Isles are compared

\begin{tabular}{|c|c|c|c|c|}
\hline & Features & A & B & C \\
\hline$\stackrel{a}{b}$ & $\begin{array}{l}\text { Forehead } \\
\text { Supra-orbital } \\
\text { ridges }\end{array}$ & $\begin{array}{l}\text { Vertical, square } \\
\text { Oblique }{ }^{\mathbf{I}}\end{array}$ & $\begin{array}{l}\text { Receding } \\
\text { Prominent, con- } \\
\text { tinuous across } \\
\text { brows }\end{array}$ & $\begin{array}{l}\text { Vertical, rounded } \\
\text { Smooth }\end{array}$ \\
\hline$\frac{c}{d}$ & $\begin{array}{l}\text { Cheeks } \\
\text { Nose }\end{array}$ & $\begin{array}{l}\text { Tapering to chin } \\
\text { Straight, long }\end{array}$ & $\begin{array}{l}\text { Long } \\
\text { High-bridged, pro- }\end{array}$ & $\begin{array}{l}\text { Wide, full } \\
\text { Short: bulbed }\end{array}$ \\
\hline$\epsilon$ & Mouth & $\begin{array}{l}\text { Lips thick, un- } \\
\text { formed }\end{array}$ & $\begin{array}{l}\text { Lips thin, straight, } \\
\text { long }\end{array}$ & Lips well formed \\
\hline $\begin{array}{l}f \\
g\end{array}$ & $\begin{array}{l}\text { Chin } \\
\text { Ears }\end{array}$ & $\begin{array}{l}\text { Small, fine } \\
\text { Rounded }\end{array}$ & $\begin{array}{l}\text { Pointed, projecting } \\
\text { Pear-shaped, chan- } \\
\text { nelled lobules }\end{array}$ & $\begin{array}{l}\text { Heavy, rounded } \\
\text { Oval }\end{array}$ \\
\hline $\begin{array}{l}h \\
i \\
j\end{array}$ & $\begin{array}{l}\text { Jaw } \\
\text { Eyes } \\
\text { Hair }\end{array}$ & $\begin{array}{l}\text { Narrow } \\
\text { Dark } \\
\text { Very dark, crisp. } \\
\text { curling }\end{array}$ & $\begin{array}{l}\text { Large, square } \\
\text { Blue-grey, sunk } \\
\text { Light-brown, } \\
\text { slightly waved }\end{array}$ & $\begin{array}{l}\text { Heavy } \\
\text { Blue, prominent } \\
\text { Light, limp }\end{array}$ \\
\hline & $\begin{array}{l}\text { Skull } \\
\text { Average height } \\
\text { Habit }\end{array}$ & $\begin{array}{l}\text { Dolichocephalic } \\
5 \text { feet } 3 \text { inches } \\
\text { (m. } 1 \cdot 600) \\
\text { Slight }\end{array}$ & $\begin{array}{l}\text { Sub-Brachyce- } \\
\text { phalic } \\
5 \text { feet } 9 \text { inches } \\
\text { (m. I. } 753 \text { ) } \\
\text { Bony, muscular }\end{array}$ & $\begin{array}{l}\text { Sub-Dolichoce- } \\
\text { phalic } \\
5 \text { feet } 7 \text { inches } \\
\text { (m. } 1 \cdot 702 \text { ) } \\
\text { Stout, well-covered }\end{array}$ \\
\hline
\end{tabular}

In the mass of the population one or other type of features is found to predominate. The prevalent type differs in different localities; and the principal cause of the difference appears to be ancestral. Progress has been made in the identification of several sub-types, especially the Gaels, Picts, Angles, and Jutes. But the definitions are not at present complete. The Committee trust that whenever ancient remains are discovered which there may be reason to believe belong to the above people, or to the Long-barrow race, they may be carefully preserved, and information forwarded to the Secretary. The long bones, which are often put away, are specially required for the purpose of ascertaining stature. They request also to be informed of the existence of any skulls in local museums or private collections, that would assist in the identification of the above types. Negatives have been taken of very pure examples of the Cymric type in North Wales, and several photographs have been purchased.

Report of the Raygill Fissure Exploration Committee, consisting of Prof. A. H. Green, M.A., F.G.S., Prof. L. C. Miall, F.G.S., Fno. Brigg, F.G.S., and Fames W. Davis, F.S.A., F.G.S. (Reporter).--The fissure occurs in an anticlinal of limestone in Lothersdale, near Skipton. The limestone is extensively quarried, and whilst removing the limestone, the fissure, which descends almost perpendicularly, has repeatedly exhibited new sections during several years past. It was decided by the Yorkshire Geological and Polytechnic Society to investigate its contents in 1879 , and a grant was made by the British Association to assist in this object. It was found that the fis ure contained, besides laminated clay and layers of sand and stones, a brown, sandy clay with rounded boulders of sand-tone and limestone derived from the immediate locality, and numerous bones of animals. The latter comprise the bones, teeth, and tusks of elephant, teeth of rhinoceros, hippopotamus, hyæna, bear, and others, broken horns of the roebuck, and bones of birds. The bones are, when found, soft and friable; and, being cemented to the matrix, are frequently difficult to extricate and individualise. The Committee express their indebtedness to Mr. Spencer, the proprietor of the quarry, and to Mr. Todd, for the kind manner in which they have assisted in the operations.

Report of Commitlee on Erratic Blocks, presented by Dr. Crosskey. - Additional facts were reported respecting the distribution of erratic blocks. A remarkable group occurs at Crosspool, near Sheffield, at a height of 730 feet above the sea. It consists of slate rocks and tuff from the Borrowdale Volcanic series of the Lake District, Carboniferous limestone and chert from North Lancashire and North-West Yorkshire. New Red Sandstone from North Lancashire, and specimens also occur which were probably derived from the East Lowlands of Scotland, with magnesian limestone from the north east of England, Near Clun, Shropshire, boulders from Rhayader and Machynlleth and neighbourhood are recorded. The highest boulder is upon Black Hill. It travelled from Rhayader, twenty-three miles we t-south-west, and has an elevation of about 1400 feet. The Report included a de icription of an enormous number of

I In place of "prominent brows." as in the repor: for 1832. boulders spread over an area of about two miles long by half a mile wide, the longer direction being south-east of Markfield, Leicestershire, from whence they were derived. It also gives an account of the erratics of the north of Hertfordshire. At KeIsall, on the ridge dividing the district draining into the Thames from that draining north and north east into the Cam, are two boulders lying about 500 feet above sea-level. The boulders noted point generally to a derivation from the Midland oolites and coal-measures, and from crystalline rocks further north. The po:ition of many boulders in the Midland Counties and the Isle of Anglesea was also recorded.

Report on the Fossil Plants of Halifax, by Prof. $W . C$. Williamson, LL.D., and W. Cash.-Clear evidence of the existence of at least two new types of Racheopteris, which are most probably stems or petioles of ferns. A third is a curious stem in which the vascular bundle approaches that of a Lepidndendron in its defined cylindrical form surrounding a cellular pith, a condition rarely seen among the ferns.

Report of the Committee to Explore Caverns in the Carboniferous Limestone in Ireland, consisting of Prof. Valentine Ball, Prof. Dawkins, and Richard 7. Ussher.-The Shandon Cave, near Yungarvan, which yielded remains of extinct Post-Pliocene mammalia in 1859 and in 1875 , has been explored during the past year. So far the work has simply been removing the loose material overlying the bone-bearing bed.

Fourth Report of the Committee, consisting of Dr. H. C. Sorby and $M r . G . R$. Vine, appointed for the purpose of reporting on Fossil Polyzoa. - Tabulates the Cretaceous Polyzoa of the British area only. Gives the classification of Cyclostomatous Polyzoa, $\& c .$, from the Silurian to the Cretaceous epochs. Describes pseudo-polyzoan forms, and gives the bibliography of the subject.

Riport of the Committee, consisting of Mr. R. Etheridge, Dr. H. Woodzuard, and Prof. T. Rupert Fones, on the Fossil Phyllopoda of the Palcoozoic Rocks. - Gives a classified synopsiof the genera of this group and detailed descriptions of certain genera.

R'port on Seismic Investigations in Fapan during the Years 1882-83, by Prof. Fohn Milne.-When in England, arrangements were made with Mr. James White of Glasgow for the con-truction of a seismometer which will give a complete diagram of all the sensible vibrations of an earthquake in conjunction with the time of occurrence of these vibrations. The results of observations on earth-tremors are given, which show that the pendulum is seldom completely at rest, that a vertical motion is occasionally observed in the pendulum, the style of which oscillates up and down with a rapid, tremulous movement. With sudden changes in the barometer, the motions of the pendulum are relatively very great. A second set of observations bas been recorded, which are the motions of the delicate levels placed beneath glass covers.

The Reports prepared by the Chemical Committees appointed at Southampton last year were read at the opening of the Chemical Section. The Committee on Chemical Nomenclature presented an interim Keport, and asked to be reappointed to complete their labours. Prof. Hartley read the Report on the Ultra-Violet Spark Spectra, which dealt especially with the disappearance of short jines, the lengthening of short lines, and alterations in the spectrum of carbon.

\section{SECTION B-ChEMICAL SCIENCE}

Sunspots and the Chemical Elements in the Sun, by Profs. Dewar and Liveing. - The authors, having made an examination of the spectroscopic observations of sunspots made at Greenwich, point out that the dark lines peculiar to spots ate not necessarily due to new elements, for cerium and titanium in the arc give a great num' rer of new lines, of which some show coincidences with dark lines seen in sunspots too striking to be merely accidental. Although a spot is less luminous than the photosphere it does not follow that its temperature must be less, inasmuch as the radiation of short wave-length generally increases very rapidly with the temperature, and the spectra of some of the metals most abundant in the sun, such as nagnesium and iron, are stronger in the ultra-violet than in the visible part of the spectrum. The unequal widening of the Fraunhofer lines in spots has an ana$\log y$ in the unequal widening of the lines of some of our elements when the density of their vapour is increased. The disappear- 
ance of some Fraunhofer lines from spots has been attributed with much probability to the emission of the upper regions of the sun's atmosphere just balancing the absorption below : the rays for which this happens are those of vapours of low tension (corresponding to Mr. Lockyer's long lines) emitted by the elements in their least complex state of aggregation. The singular ray with wave-length 4923 , which is a line of iron of high vapour tension, but behaves in the sun as a line of low vapour tension, being frequently seen high up in solar storms and disappearing from spots, probably belongs to some other metal as well as iron.

Mr. R. Meldola read a paper on The Colouring Matters of the Diazo.Group, in which he gave an historical sketch of this important class of bodies discovered by Dr. Griess, and proceeded to describe a number of new compounds in which the diazo-grouping occurred three times. These compounds prepared by the author yielded excellent dyes, specimens of which were exhibited. The great importance of these new products was shown by the fact that since their introduction the cochineal industry had gradually declined.

Mr. H. B. Dixon exhibited tubes in which a dried mixture of carbonic oxide gas and oxygen was submitted to the electric spark. The tubes were shaped like the letter W, the two outer arms being open and sealed with mercury in the two lower bends. In one arm of each tu'se anhydrous phosthoric acid had been introduced to dry the gaseous mixture. The tubes had been so charged for a period of three days. On passing the spark at the top of the central bend, a very slow and quiet combustion was propagated down the tube in which no plosphoric acid had been placed, but no combustion was propagated down the tube containing the phosphoric acid. In an experiment with another similar tube, only a small fraction of the mixture ignited in one arm. Water was then introduced by a pipette into the mixture, and after the steam had diffused, the spark was passed, producing a loud explosion.

Prof. A. W. Williamson in discussing the Chemical Constitution of Matter remarked that when any sufficiently careful attempt has been made to decompose one of our elementary substances this attempt has always failed. Referring to Prout's hypothesis that the atomic weights of the elements were exact multiples of that of hydrogen, Dr. Williamson showed that this idea had been fruitful because it had led chemists to make most accurate and conscientious determinations of atomic weights. The result of the labours of Mendeléeff, Lothar Meyer, and others has shown that the elements belong to a natural family, and has given an authority to the established weights which could not be assigned ti) them previously on chemical or physical grounds. When chemists speak of matter, they always limit themselves to that which can be " eighed : it would be better to throw off that limitation and not hamper our ideas with a condition which may some day have to be removed. What many chemists have regarded as the most fundamental property of matter, its weight, may not be an inherent property in the matter itself, but may depend on forces reacting between the "matter" and the ether surrounding it. All that we know about the atomic weight of atoms is not inconsistent with varieties among individual atoms, but only proves that the average weight of large aggregates of atoms is the same.

Prof. Dewar read papers, by himself and Mr. A. Scott, on The Atomic Weight of Manyanese and on The Molecular Weights of Sulistitutel Ammonias, in the latter of which the authors pointed out the advantage of using the molecular weights of these compounds for accurately determining the relation between the atomic weights of hydrog $\mathrm{n}$ and carbon of which elements several atoms are cuntained in the introduced radicle. The anthors conclude from their experiments that if oxygen be taken as I6, the atom of hydrogen must be less than unity, and not larger, as is the generally received opinion.

Prof. W. Ramsay, in a paper on The Application of Bisulphite of Carbon to the Scouring of Wool, drew attention to a curious difference in the quality of the bisulphide manufactured in France and England.

The Rev. W. A. Irving exlibited tubes in which trioxide of phosphorus had been sealed up and exposed to sunlight. The tubes contained dark crystals of phosphorus. The author stated that on opening the tubes he found pentoxide of phosphorts present, and aryued that the sunlight had decomposed the trioxide into free phosphorus and the pentoxide. In the discussion it was suggested that free phosphorus might have been sealed up together with the oxide, and have changed its condition on exposure to sunlight.
Prof. Dewar pointed out an important relation between the critical temperature and pressure of volatile liquids and their molecular volumes. The ratio of the critical pressure to critical temperature is proportional to the molecular volume, so that the determination of the critical temperature and pressure of a substance gives us a perfectly independent measure of the molecular volume. Prof. Dewar pointed out the great advantage of enploying a liquid of low critical temperature and pressure such as liquefied marsh gas for producing exceedingly low temperatures. He hoped to be able to approach the absolute zero by the evaporation of liquefied marsh gas whose critical temperature was less than - $100^{\circ}$ Centigrade, and whose critical pressure was only 39 atmospheres.--Sir W. Siemens hoped Prof. Dewar would soon succeed in producing a temperature near to the absolute zero, as he had the greatest desire to test at such a low temperature the magnetic and electric behaviour of metals.

Dr. Gladstone, in a paper written in conjunction with $\mathrm{Mr}$. Tribe, on The Electrolysis of Dilute Sulphuric Acid in Secondary Batteries, was led to the conclusion that besides the molecula: change in the electrolyte, there was also an actual passage of sulphuric acid into the limb containing stlphate of copper. No data exist to decide the question whether it is sulphuric acid or some hydrate of it that is electrolysed, but analogy would lead to the conclusion that it is sulphuric acid.

Mr. H. Brereton Baker, in a paper on The Alleged Direct Union of Hydrogen and Nitrogen, described the carefully conducted experiments he had made with nitrogen, derived without heat from the air, and pure hydrogen. These gases led over hot platinum sponge gave no trace of ammonia. He found that, in an apparatus similar to that used by Mr. Stillingfleet Johnson, the oxides of nitrogen produced by the passage of hydrogen through the nitrate of silver solution used to purify it were not completely arrested by the ferrous sulphate absorbers, so that the ammonia produced in Mr. Johnson's experiments was doubtle:s due to the action of these oxides on hydrogen in presence of hot platinum.

Messrs. Friedel and Crafts communicated a paper on The Decomposition of Hydrocarbons by Aluminic Chloride. Chloride of aluminium is not only a synthetical agent but also a reducing agent cau-ing the sub titution of hydrogen for methyl, ethyl, \&c. For instance naphthalin distilled with 25 per cent of aluminic chloride gave a distillate of benzene and hydrides of naphthalene. Benzene, heated to $235^{\circ} \mathrm{C}$. in a sealed tube with the chloride, gave off marsh gas on opening, and the contents of the tube on distillation with water gave hydrocarbons boiling at from $80^{\circ}$ to $160^{\circ}$. Diphenylmethane, distilled with chloride, gave a distillate containing benzene and toluene. Triphenylmethane clistilled with more than half its weight of chloride gave only benzene. Hexamethylisenzene heated with one-third its weight of chioride gave off plenty of a non-illuminating gas; froin the residue crystals of durene were deposited. In the case of the poly-methyl benzenes one or more methyl groups are replaced by hydcogen with the formation of very little hydrochloric acid. The same equation previously adopted to explain the synthesis of hydrocarbons by aluminic chloride, is sufficient to explain the present decomposition :-- $\left.\mathrm{C}_{6} \mathrm{H}_{6}+\mathrm{Al}_{2} \mathrm{Cl}_{6}=\mathrm{C}_{6} \mathrm{H}_{5} \cdot \mathrm{Al}_{2} \mathrm{Cl}\right]_{5}+\mathrm{HCl}$. The compound $\mathrm{C}_{6} \mathrm{H}_{5} \cdot \mathrm{Al}_{2} \mathrm{Cl}_{5}$, is broken up by heat into diphenyl and aluminous chloride; the latter is decomposed by the free hydrochloric acid into aluminic chloride and hydrogen, and the hydrogen thus set free exerts the reducing action. The Section recommended the paper for publication in extenso in the Transactions.

Prof. B. Warder of Ohio, U.S.A., communicated a short paper called Suggestions for Computing the Speed of Chemical Reactions. He recommended for unit of volume the cubic centimetre, for mass the chemical equivalent expressed in milligrams, and for time the hour. Prof. Warder drew attention to the fact that many determinations of the rate of etherification had been published for twenty years, and yet no mean value of the "rateconstant" had been worked out. Such calculations might fitly be undertaken by students at colleges, and the Chemical Section of the Ohio Institute had begun such work and invited the assistance and cooperation of clemists engaged in teaching.

Mr. P. M. Parsons gave an account of different varieties of manganese-bronze prepared by heating copper with ferro-manganese. The spiegeleisen, as in the Bessemer process, removes the oxygen from the copper, with which part of the manganese forms an alloy of extraordinary tensile strength. One of the varie ties, capable of resisting a great transverse strain, is largely employed for making screw-propellers. These are cast in sand. 


\section{SECTION E}

GEOGRAPHY

Opening Address by Lieut.-Colonel H. H. GodwinAusten, F.R.S., F.G.S., F.R.G.S., \&c., President OF THE SECTION.

My predecessor, Sir Richard Temple, selected for the subject of his address to this Section last year "The Central Plateau of Asia," and he treated it not only from a broad and general geographical, but also, and to some extent, a political and historical, point of view. Following him, in a measure, over some of the same ground, I have selected the mountain regicn south of the Central Asian highlands-viz. the Himalayas, and more particularly the western portion of that range, as the subject of this paper. I propose considering this mountain chain with reference to its physical features, past and present ; and consequently with reference to its geological history, so far as that relates to later tertiary times-i.e. the period immediately preceding the present distribution of seas, land, rivers, and lakes. It is not, however my intention to enter very deeply into the purely geological branch of the subject.

Comparatively little of the earth's surface now remains unexplored, but much remains to be surveyed and examined in a more scientific manner. Within the last fifty years explorers have made known to us the general features of those dotted or blank spaces which, as boys, we used to look at in our school atlas sheets with so much curiosity, mingled with no little desire to discrver the hidden secrets of the unknown lands so shown. The student of the present day enjoys information more or less accurate respecting countries which to us were mere speculative shadows.

But there are other atlas sheets beneath, and only a very few feet beneath, those of this present day, which are closely connected with the latter, and beneath them again others lie still deeper which have modified the geography of this earth over and over again. It is to such a sheet or two relating to the great Himalayan chain that I now invite your attention. If we wish to deal with physical geography (and to my mind it has equal charms with either pure geography or exploration), our inquiry must, if we wish it to be of any really scientific value, be based on geological structure. We must study the ancient atlas sheets, one by one, which nature is, day by day, revealing to us by the denudation of the present surface, taking away and building up the material for atlas sheets of future epochs. Geography and geology are very intimately related; each is truly based upon the other. Local changes of temperature on the surface of this earth, and internally the slow shrinking of its crust, have effected gigantic changes of its surface, and are still altering the topographical features of every country. Directly we look back in time and space and note what changes have taken place, the science of geology steps in, and with it mathematics, chemistry, batany, and zoology. A raised sea. beach with its dead shells, or a submerged fore:t with the remains of its former fauna and flora, geologically an event of yesterday, sends us back thousands of years into the past, thinking of what were the aspect and dimensions of the former land ; therefore, to be a good geographer, something should be known of geology and its kindred sciences. This will be my excuse if in this address I dip somewhat below the surface, and, as some may think, introduce too much geology into this Section. The basis, however, of this branch of knowledge is geography, and this the Royal Geographical Society and the British Association in this particular Section do all they can to foster. There is no gainsaying the fact that very many of our ablest men of science, the ablest naturalists and geologists this country has produced (and it has taken a leading part in geology), have commenced their careers in connection with geographical exploration. Darwin's earlier studies were prosecuted whilst he was attached to marine surveys in other parts of the world; through the same school passed Huxley and Edward Forbes. There was no better example of an able geographer and geologist than Sir Roderick Murchison, who for years took a leading part at these meetings. The list might be largely extendedSir Joseph Hooker, Wallace, Wyville Thomson, Moseley, \&c. That most seductive of all studies, the geographical distribution of species, is intimately connected with geographical exploration. Just as the navy owes much of its efficiency to our coasting and mercantile marine and to our hardy fishermen, so have geography and other sciences been strengthened by the labours of those practical and scientific men who have been engaged in marine or territorial surveys.
The Himalayas, the highest mountains in the world, have excited the interest of many travellers and many geographers; very much has been written about them, some from personal knowledge, and a good deal on second-hand information. Much confusion has resulted from the features of the north-western area being so dissimilar in composition to those of the rest, or eastern part, of the chain, and the limitation placed on the breadth and extent of the whole as a mountain mass. There has been a tendency to apply the term "Himalaya" in too extended a sense : it should, I consider, be restricted to those portions which dominate the plains of India, from the inhabitants of which country we have derived the name. This would, strictly speaking, apply only to the snowy range seen from the plains of India bordering upon the course of the Ganges; but we might, I think, use the term in an extended sense, so as to include that which we may call the north-western Himalaya, nortk of the Punjab, and also the eastern Hirnalaya, bordering on Assam.

The orography of this mountain mass has been recently ably handied by Messrs. Medlicott and Blanford, ${ }^{1}$ and I follow them in all their main divisions and nomenclature, which are based upon a thorough understanding of the rocks of the country. Some line must be selected where the term Himalaya in its uidest sense must cease to be used, and this certainly cannot be better defined than by the valley of the Indus from Attock to Bunji. On this line we find the great bending round or change in the strike of all the ranges. Strictly speaking, the change commences on the south, where the Jhelum River leaves the mountains, but this line, north of Mozufferabad, continues on into the above-mentioned part of the Indus valley. To the mountains north of the Indus on its east and west course the name Himalaya should certainly never be applied. For this north-west, Trans-Indus part of the Asian chain we have the well-known name Mustagh, so far as the head of the Gilgit valley; the Hindu Kush being an excellent term now in common use for its extension to the Afghan country.

The observations made by many of the assistants of the Indian Geological Survey, more especially by Stoliczka, and more recently by Lydekker ${ }^{2}$ in the Himalayas, combined with those made by myself in the same region, have, when considered in conjunction with the ascertained strike of the granitoid or gneissic rocks, led me to separate the great Central Asian chain into the following five principal divisions, with some minor subdivisions :-

\section{Central Asian Chain. ${ }^{3}$}

\section{The main axis or Central} Asian, Kuenlun

2. Trans-Himalaya

\section{Himalaya}

4. Outer or Lower Himalaya 5. Sub-Himalaya

I use the word "chain" in its widest meaning, so as to comprise the whole length and breadth of a mountain mass, and not, as it has been sometimes used, to describe a "chain" or single line of mountain peaks.

I show these and the equivalent ranges of other geographers and authors in the accompanying synoptical form ; and if sections be made, at intervals of about 100 miles apart, through the whole mass of the chain from the plains of India to Thibet, they show where the different ranges are locally represented, and hnw they separate or are given off from the main axis lines. The same scale for both vertical and horizontal measurements should be used, because there is nothing more misleading than sections in which an exaggerated vertical scale is used. In our present state of ignorance as to the composition of the chain eastward from the source of the Sutlej, we cannot attempt to lay down there any axis lines of original elevation. The separation by Mr. Clements Markham ${ }^{4}$ and Mr. Trelawney Saunders ${ }^{5}$ of the line of highest peaks into one range, and the water-parting into another, is an acceptable solution of the physical features as at present known of this part of the chain. I am led to think, however, that when this ground is examined it will resolve itself into a series of parallel ridges more or less clo e, and oblique to the line of greatest altitude as defined by the line of high peaks, crosing diagonally even the main drainage line of the Sanspu, just as we see the Ladak axis crossing the Indus

I A Manual of the Geology of India, 1879, p. 9.

2 Memoirs of the Geology of India.

3 Consult Atlas Sheets of the Indian Survey, $\mathrm{I}$ inch $=4$ miles, and latest map of Turkestan and the countries between the British and Russian dominions in India- $\mathrm{r}$ inch $=32$ miles. Compiled under the orders of Lieut.-Gen. J. T. Walker. C.B., R.E., F.R.S.

4 Thibet. Boyle and Manning. Introduction.

5 Geographical Magazine, July, 1877, p. 173. 
near Hanlé, or the Pir Panjal that of the Jhelum. Sir Henry Strachey's conception of the general structure was the soundest and most scientific first propounded. ${ }^{1} \mathrm{He}$ considered it to be

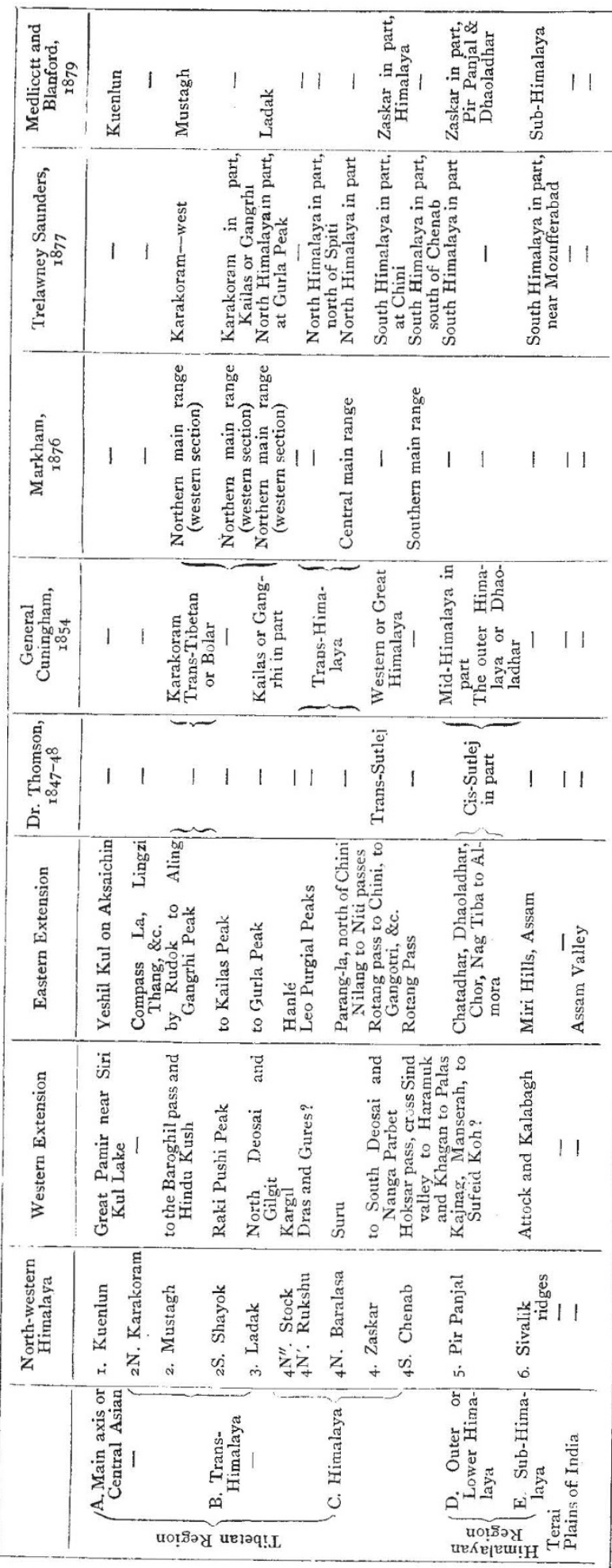

made up of a series of parallel ranges running in an oblique line to the general direction of the whole mass, the great peaks 1 "Physical Geography of Western Thibet," Royal Geographical Society's Journal, vol, xxiii. p. 2 . being on terminal butt-ends of the successive parallel ranges, the watershed following the lowest parts of the ridges, and the drainage crossing the highest, in deep gorges directly transverse to the main lines of elevation.

It will be seen from sections, drawn as above, that the mountain mass of the Himalayas increases gradually in height from the south tn about its central portion and then as gradually falls towards the north side. There is no abrupt and conspicuous slope from the higher line of peaks to the plains; a succession of spurs from the main water-parting intervenes, and these spurs retain often a very considerable altitude far to the south. The spurs terminate, usually, abruptly towards the plains of India, at an altitude of 5,000 to 8,000 feet, just within a more or less broad belt of fringing low hills, the well-known Sivaliks.

It has been laid down that the Himalayan chain culminates in two parallel ranges running through its entire length from the Indus to the Brahmaputra, and these have been called the north and south Himalaya, or central and southern; the two combined (they are very close in parts) really constitute the above chain. We can apply this system to certain portions of the range, but it breaks down when we reach the Sutlej on one side and the Monass on the other. The more we increase the scale of our map:, the greater the number of axial lines we can establish, all intimately connected with, and subsidiary to, the run or strike of the greater series of axial elevations.

\section{Explanation of the Different Ranges}

I. Kuenlun Range.-The most westerly extension of this granitoid axis is found W.N.W. of the Zangi-diwan pass at Oikul and the Victoria Lake. Here Stoliczka records it ${ }^{1}$ with slates and schists resting on it to the southward. Now the next great granitoid axis south of the above, with palæozoic rocks on its northern face, is at the Mustagh pass, fifty miles to the south of Kuenlun at Zangi-diwan, and it coincides in position with the gneiss of Kila Panza, ${ }^{2}$ the granitic axis of the Mustagh being continued W.N.W. in the high peaks of Hunza-Nagar. The Kuenlun axis passes by Shahdula eastward by peaks E. 6I, 23,890 , E. $64,21,500$, up to Yeshil-Kul on the Keria route, for a distance of about 450 miles; beyond this is unexplored country.

I have adopted the term Mustagh as one well known to the people on both sides of the range, and better known than Karakoram, applied by them to the pass of that name. The Karakoram pass also lies on an axis of elevation further to the north and intermediate between the Mustagh and Kuenlun.

2. Mustagh.-This axis, as I have shown above, commences near Kila Panza in Wakhan, thence by the Baroghil and Keram. bar passes to the great peaks dominating the Hunza valley to the Mustagh pass, eastward by $\mathrm{K}_{2}, 28,250$, to the great peaks north of the Shayok, $\mathrm{K}_{9}, \mathrm{~K}_{10}, \mathrm{~K}_{11}, \mathrm{~K}_{12}{ }^{3}$, the Sassar pass, and thence S.E. on to the Marse Mik La and the high mass north of the Pangkong Lake, crossing at Nyak Tso on to the high ranue south of the Rudok plain, where we again enter unsurveyed ground. It is probably continuous to the Aling Gangri, the old original drainage of the Shayok passing through it at the Pangkong Lake, thus repeating in a similar way that of the Indus through the Ladak range near Hanlé. This most remarkable depression of the whole area, the Rudok plain, lies S.E. of the Pangkong Lake, where, on the same meridian as the sources of the Indus and Sanspu, we have a plain only a little above I 4,000 feet, which once drained in glacial and pre-glacial times into the Shayok, rendering that branch as long as, probably longer than, the present Indus. From a high point above the Pangkong I have looked over this plain ; for a distance of some sixty miles it was seen bounded to the south by mountains of over $2 \mathbf{1}, 000$ feet, and no mountain ranges broke the horizon. The depression is a broad and continuous one here, lower and more extensive than that at the head of the Indus. It is not improbable that it indicates the head waters of the next great drainage area north of the Indus, viz. of the rivers that find an exit to the sea through Burmah. The Gang-rhi and Karakoram, or Mustagh, cannot be therefore considered as one range separating the Indus basin from that of the northern or central plateau of Thibet. This must lie across the broad elevated plateau that extends from the Karakoram pass, having a general parallelism to the Kuenlun certainly so far as $34^{\circ} \mathrm{N}$. and long. $82^{\circ} \mathrm{E}$.

The crystalline limestone near the west end of the Pangkong Lake would appear to be the same as the similar limestone

I Scientific Results of the Yarkand Mission, p. 38.

2 Stoliczka, loc. cit. p. 38 .

3 Unknown and unnamed peaks were thus designated during the progress of the triangulation. 
at Shigar near Scardo. It comes in, too, on the north side of the great gneissic axis, the northern boundary of which follows the Shayok River pretty closely from Tanksé and Shayok to Khapalu. The foldings in the gneiss which have caught up the palæozoic slates near the Tanksé are again on the west indicated by the metamorphic schists on the Indus south of Kartaksho, and by those in the section S.W. of Scardo.

$2 \mathrm{~N}$. Karakoram-Lingzi Thang Range.-West of the pass the country is not known. Eastward the line of elevation passes north of the Dipsany plain to the Compass La, and south of the Lingzi Thang plain, by the Changlung Burma La to the neighbourhood of the Kiang La, and thence still further east it may pass north of Sarthol into Garchethol.

3. The Ladak-Gurla Range.-This is the best defined, as a continuous granitoid axis, on the east and west of Leh; the Indus flows at the base of its escaryment for 190 miles, and this line also was not far from the limit of the ancient nummulitic sea. On the west it unites with the great plateau of Deo:ai and extends to Gilgit. The Indus drainage has cut through it from south to north into the Scardo basin, and back again to south at the sharp bend at Bunji, while on the east at Hanle the same river passes to the north again, and the range is continued following the left or south bank up to the Gurla peak, south of the Mansarowar Lake. Thence it is probably continuous up to the Fotu La.

2S. The Shayok-Kailas. - This subsidiary axis is well marked on the south of the Pangkong Lake N.W. and S.E. of Tanksé, running parallel to the Ladak range. It is then to be followed westward, north of the Shayok River to the junction of the Basha Braldoh Rivers, and thence to Haramosh and Raki Pushi peaks, and perhaps through Yasin to Tirich Mir on the Hindu Kush. To the eastward from Sajam peak, the north side of the Indus and Gartangchu to the Kailas peak, thence very probably north of the head waters of the Brahmaputra.

4. The Zaskar Range, where best displayed, is that portion which lies south of the districts of that name in Ladak, and running parallel for 100 miles with the upper sources of that large tributary of the Indus, the river of the same name. In the size of the present glaciers that fill the upper valleys, this portion more closely resembles the Alps of Europe than any other part of the Himalayan chain. It is continued to the N.W., past Dras, to the southern side of the Deosai plains, thus coalescing with that great elevated mass of the primitive rocks. It is continued to the Nanga Purbet, 26,620 feet, and it probably continues still further, west of the Indus, the curve of the range bounding Swat and Bajaur on the north towards Kunar, and which, atter the central portion, we may term, at present, the Bajaur range. Taking it up in a S.E. direction, it bends slightly south, crossing the hedd of the Bagha River by the Rotang pass to that line of lofty snowy peaks seen from Simla and other hill stations leading past Chini to the east of the Sutlej, to the famous peaks of Gangotri, Nandadevi, and Nampa. To the majority of Europeans who have visited India this is perhaps the best known portion of the Himalayas.

${ }_{4} \mathrm{~N}^{\prime}$. The Rukshu Ridge. - Two secondary ranges, more or less connected with the last, one intimately so with an axis of trappæan intrusion of early tertiary age, which from Dras to the Mansarawa is over 400 miles in extent, can be followed. The first is conspicuous at the 'Tsomorirhi Lake, Mata Peak, 20,600 feet, boing of granitic rock; it is seen on the west covered by the earlier sedimentary formations, but it can be traced towards Dras, and on the S.E. to the Imis La, curving thence towards the Leo Purgial ma:s, the elevated tertiary formations of Hundes coming in on the east.

${ }_{4} \mathrm{~N}^{\prime \prime}$. The Stok.-Another subsidiary and later line of elevation, one I had at first been inclined to disregard in this address, being a minor feature in comparison with the whole chain, flanks conspicuously (attaining the very considerable elevation of over 20 , 000 feet) the left bank of the Indus for 200 miles, and is still more intimately related to the above trapprean intrusion. It forms a connecting link with the tertiary rocks of the same age on the southern base of the Himalayas (the elevation of which led on successively to the formation of the outermost range of hills, the Sivaliks), and shows the relatively recent date of the elevation of the whole chain, and the obliteration of the topographical details of a previous mountain mass.

4N. The Baralacha Ridge.-This line of elevation corresponds with the run of the highly tilted slates, carboniferous and succeeding formations resting against the Zaskar axis, which it follows from near Surt to south of Padam by the Baralacha and Parang passes; here, for a short distance constituting the water- parting between the Indus and Chandrabagha, it can be traced towards the Sutlej, Chini, crossing on to the Keobrang, and in turn the Nilang, Niti, Lakhur, and Tinkar passes, displayıng all along this line its characteristic feature, first seen at the Baralacha pass, of being the main water-parting between the Ganges and Kali basins on the south, and the Indus on the north, and constituting from here to the eastward, with the peaks on the granitic or gneissose axis, the main Himalayan range. In the Nipal area to the eastward, we notice the great similarity with which one river basin follows the other, the only difference being that the watersheds of some lie further to the north than others. We may thus, I think, infer that the above character of the Baralacha axis is the type of the physical features along this unsurveyed, little-known territory until we reach the longitude of Darjiling.

4s. The Chenab and North Kashmir.-South of the Chenal, River, running parallel with it for many miles, is another gneissic axis, through which the Chenab passes into a sharp bend to the south near Kishtwar; the peak of Gwalga well marks its position here, and the strike of the same rock is continued towards the northern outer hills of the Kashmir valley hy Barrapatta and Dalwas Peak, near the Hoksar pass, and the Maro Wardwan valley below Ainshin. For some distance the stratified rocks only are seen, but on the Boodpathar ridge near Srinagar and in the Sind valley, and again from near Haramook Peak to Tragbul, the gneissic rocks appear. Further still they occur in the hills at the head of the large tributaries of the Kahmil River, and thence I suspect are continued across the Kishengunga to the snowy peaks above Wamba and into Khagan. On the S.E. at the Rotang pass at the head of the Beas valley it unites with the Zaskar axis.

5. The Pir Panjal-Dinoladhar Ridge.-On the outer face of the chain there is a well-marked gneissic or granitoid axis. It is well exemplified in the Dhaoladhar ridge above Dharmsala, directly connected with, and equally well displayed in, the Chatadhar ridge south of Budrawar; thence it can be traced to the Chenab, which breaks through it here, to the south-east side of the Kashmir valley, forming the eastern end of the Pir Panjal range. We find it at intervals amidst the older slates along the ridge westward, and close up to the gorge of the Jhelum River, where it leaves the valley of Kashmir. It reappears on the other side of the Jhelum in the Kajnag ridge towards Mozufferabad. The gorges of the Kishengunga and Khagan Rivers are near this place, and to the westward the granito:d rocks are again met with at Manserah in the Hazara valley. Little is known of the mountains to the north of this, but the axis apparently crosses the Indus near Amb, curving round in the Yusufzai Hills north of the Peshawar valley, the Sufedkoh being an analogous range on the south of the Kabul River. Returning to the Dhaoladbar ridge, the granitoid axis continues to Sultanpur on the Beas across that river, by Tuket to Hatu, across the Sutlej to Kuper and Kanchu Peaks, and the well-known peak of the Chor. Nag Tiba, north of Mussoorie, would mark its eastern extension, beneath the slates of that ridge, and beyond Dudatoli and Binsar Peaks, and A mora to the Kali River, ${ }^{1}$ near Meenda Ghur. This axis thus holds the same position with regard to the plains of India and at about the same distance from their base for a very great distance.

6. The Sub-Himalaya.-This longitudinal section of the Himalaya is easily defined by the fringing line of hills more or less broad, and in places very distinctly marked off from the main chain by open valleys (dhuns), or narrow valleys parallel with the main axis of the chain.

The Eastern Himalaya.-In Western Bhutan, beyond Darjiling, between the Juldoka and the Am Mochu, the gneissic rocks have a N.W. strike by the Pango La, apparently towards Kanchinjunga; to the S.E. by Betso Yeak to the Singchula above Buxa. Hooker records Kinchinjhow as of granite, with stratified rocks to the north. This axis may possibly be continued E.S.E. to Chumularhi and the gneiss of the mountains north of Paro.

In the far east, in the Dafla Hills, a more general parallelism of the ranges from W. to $\mathrm{E}$. is found, assimilating to the N.W. area. A well-marked granitoid axis is to be traced from S.W. to N.E. (the outer Himalaya here), convex to the S.E., the tertiaries or the Sub-Himalaya being of considerable breadth and elevation, and following the same curve. Considerable valleys or dhuns are also again a feature on this side.

Lastly, there is the Assam range, which, although not forming a part of the Himalayan mountain system, I must allude to, as

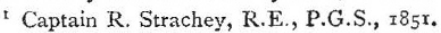


I shall have to refer to it further on. This is very clearly defined by a gneissic axis on its southern margin, against which the secondary rocks rest, and by a more northern line of the same primitive rock, succeeded by another of isolated low hills following the northeru base and the course of the Brahmaputra, and generally lying to the north of it. The last outcrop is seen at Dhoobri, and thence it is no doubt continuous across the delta to similar outcrops of Bengal gneiss on the Ganges, thus connecting this axis of elevation with that of peninsular India. The above range is convex to the south, curving up to the N.E. in the Lhota Naga and Nowgong Hills, and to the W.N.W. in the Garo Hills.

The Burrail range forms another subsidiary line of elevation to the above frum the Naga Hills to Jaintiapur, and falls away dipping under the Sylhet bhils, ${ }^{1}$ to reappear at the most $\mathrm{S}$.W. point of the Garo Hills. From its highest point in the Naga Hills (Japvo), where the strata become nearly horizontal, it merges into and throws off the high $\mathrm{N}$. and S, ridges that bound the Munipur valley on the west, to join the Lushai Hills on the south. This I would call the Western Munipur and Arakan range. It has no granitoid axis ; but to the N.E. of Munipur a great mass of intrusive rock occurs at the high peak of shuruifurar, and thence a high line of elevation runs N.N.E. to Saramethi Peak, and to the south forms the eastern boundary of the Munipur valley, and might be called the eastern Munipur range-it is the water-parting between the above valley and that of the Kyangdweng.

We ca", in a measure, exemplify the structure of the Himalaya by that of the bones of the right hand, with fingers much elongated and stretched wide apart, of which the wrist and back may represent the broader belt of granitic rocks of the eastern area, the thumb and fingers the more or less continuous ridges of the N.W., some less prolonged than others to the north-west, such as the Chor axis, which may be represented by the thumb, terminating on the southern maryin near the Sutlej. The left hand placed opposite will represent the same features to the west of the Indus. We will even carry this simile further, and as a rough illustration suppose the intervals or long basins between the fingers to be filled with sedimentary deposits, and the fingers then to be brcught closer together, producing a crushing and crumpling of the strata. At the same time an elevation or depression, first of one or more of the fingers, then of another or of the whole hand has taken place, and you are presented with very much what has gone on upon a grand scale over this vast area. As these changes of level have not taken place along the whole range from $E$. to $W$. in an equal extent, but upon certain transverse or diagonal lines, undulation more or less great have been the result, and some formations have attained a higher position in some places than in others, prodncing, very early in the history of these mountains, a transverse system of drainage lines, leading through the long axial ridges.

The last efforts of these rising, sinking, and lateral crushing, and, as I believe, very slowly acting forces, are to be seen at the southern face of these mountains in the tertiary strata that make up the Sub-Himalayan axis (Sivalik) a topographical feature which is most striking by reason of its persistence and uniformity for some 1600 miles; for, although a similar and synchronal elevation of the Alps has taken place, the same regularity of orographical features has not been the result, most probably from the difference in the original outline of deposition in the latter area. One object in this address will be to endeavour to point out and compare some of the physical features of the two great European and Asiatic chains.

From Assam on the east to the Punjab on the west, bending round and extending to Scinde, this fringing line of paralle ridges is found at the base of the Himalayas, sometimes higher, sometimes wider, often forming elliptical valleys. Only in one part of the belt east of the Teesta are they absent altogether, and for a distance of fifty miles the metamorphic rocks ri $e$ directly from the plains of India, ${ }^{2}$ a feature representing a great break-the correct interpretation of which will tell us very much of the past hi-tory of these mountains. These formations are of vast thickness, and in the Punjab, where they attain their greatest width and elevation between the Chenab and the Indus, cover an area of 13,000 square miles.

The whole of this material has been derived from the adjacent Himalayas, representing many feet of the older and higher I "Bhil" or "jhil"'-Hind., a marsh.

Memoirs of the Geological Society of India, Medlicott, vol. iv. pp. $39^{2}$ and 435 mountain ranges, and has travelled down valleys that have been excavated in pre-tertiary times. This points to a slow subsidence of the whole southern side of the mountain mass, deposition generally keeping pace with it, broken off by recurring long intervals of re-elevation. Such important, well-marked features as these cannot be omitted when treating of a mountain system. Many long and instructive pages of its history are written on these rocks, with the help of which we may reconstruct some of the outlines of its more ancient geography.

The next most interesting feature connected with the former distribution of land and sea is that these Sub-Himalayan formations are fresh-water, or torrential, showing that since nummulitic or eocene times the sea has never washed the base of the Himalayas. ${ }^{1}$ In fact, there is no evidence of this from the gorge where the Ganges leaves the mountains up to the base of the Garo Hills ; pointing to an extension northward at that early age of the Arabian Sea, separated from the Bay of Bengal by penin. sular India. I am led also to believe that from Assam to Scinde there once existed one continuous drainage line, a great river receiving its tributaries from the Himalayas, partly a land of lakes aud marshes, the home of that wonderful mammalian and reptilian fama which Cautley and Falconer were the first to bring to light. In pliocene times, before the greater displacements commenced, it is not unlikely that the Kashmir basin drained at the north-west end into the Kishingunga Valley to Mozufferabad, and that of Hundes and Ladak trended towalds the same direction vîa Dras.

The southern boundary of this long alluvial plain was formed by the present peninsula of India, and probably of the extension of the Garo and Khasi Hills westward to the Rajmahal hills." Depression has been considerable in the neighbourhood of Calcutta, ${ }^{3}$ nearly 500 feet. We know probably only a portion of the alluvial deposits. At 380 feet beds of peat were passed through in boring, and the lowest beds contained fresh-water shells; the beds also were of such a gravelly nature as to indicate the neighbourhood of hills, now buried beneath the Ganges alluvium. This is precisely the appearance of the country above Calcutta on approaching the present valley of the Brahmaputra. The western termination of the Garo Hills sinks into these later alluvial deposits, and along the southern face of the range up to Sylhet, the waters of the marshes, ${ }^{4}$ during the rainy season wash the nummulitic rocks like an inland sea, and point to the very recent depression of all this area. The isolated granite hill-tops jutting up out of the marshy country from Dhoobri to Gwalpara and on to Tezpur all testify to the same continuous depression here. It is exactly north of this that we find the Sivalik formations absent at the base of the Himalayas, and we have the evidence of exclusively marine conditions in pliocene times at the base of the Garo Hills. ${ }^{5}$ We find also a large development of narine bed; above the nummulitic limestone in the Jaintia country, ${ }^{6}$ passing up comformably into a great thickness of upper miocene sandstones of the Burrail range. In such sandstone north of the Munipur valley the only fossils $I$ found were marine forms.

This gradual depression of the delta of the Ganges, the relative higher level of the water-parting and shifting of the Punjab rivers westward, appear to be only the last phase of that post-pliocene disturbance which broke up the As am Sub-IHimalayan lacustrine system draining into the Arabian Sea. Zoological evidence which I cannot here find space to quote is also in favour of this former connection of the now separated waters of the Ganges and Indus basins, and the hill tracts of the Garo and Khasi Hills with peninsular India.

The ground where the miocene rocks are absent is not where any denuding force from the north could have acted with any abnormal intensity. It lies under the hills where no great tributary enters the plain, and might have removed the above formation. All the evidence is in favour of the axis line of depression in the Ganges delta betwe in Rajmahal and the Garo Hills extending thus far, and that the miocene beds, once continuous, are here thus lost to sight beneath the more recent yct extensive gravels and conglomerates that here occur, and have partaken also of a last slight elevation of the mountain chain.

Even if we were to raise the rocks below the delta up to the

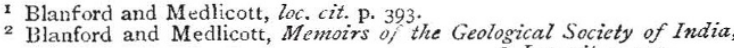

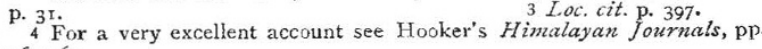
$26_{3}-265$.

5 (Colebrooke, Geological Transactions, vol. i. p. 135

6 H. H. Godwin-Austen, J. A. S. B. 1869 , pD. 12 and 152. 
maximum level of the Garo Hills, about 4000 feet, it would not be a greater alteration of level than we can see now a very few miles distant to the east. The base of the cretaceous formation rests on granite at the peak of Kailas, about 3000 feet above the sea; at thirty miles eastward it is at the level of the plains of Sylhet, scarcely removed above that level; it is here we find a remarkatle depression right across the Assam range from north to south, which it is curious to note faces immediately the Monas; valley of the Bhutan Himalaya.

Great lateral rolls or waves of the stratified rocks occur at in tervals all along the southern line of the chain, and apparently have a connection with the transverse drainage line. This feature is best seen if we follow the old miocene along its junction with the older rocks. The miocene attains its greatest elevation at Bisari and Keeran Peaks-I I,200 feet-close to the end of the Pir Panjal axis ; it falls thence towards Mari to 7000 feet, and much lower towards the Potwar. Eastwards it is reduced, above Poonch, to 9900 feet; near Rajaurie to 7000 feet, and Kamrot 6700 feet-or a fall of 4500 feet in fifty miles. The elevation increases again, upon the Chenab, to $8 \mathrm{coo}$ and $95 \mathrm{co}$ feet; and, facing the Chatadhar ridge, it is again of great elevation-9096 feet at Hato Peak, and Mandhar 8932 feet. At the Ravi, by Basaoli, there is a depression, east of that river to 4600 feet, but it gradually rises again to 6100 feet at Dhurumsala, under the Dhaoladhar ridge, and retains that altitude to the Beas and Sutlej, where it falls again to 4000 feet, which is its altitude about Nahun and the Jumna. In the Deyra Dhun it is only 3000 feet, but east of the Ganges, where there is a local bend in the strike, it rises again considerably. Beyond this the country has not been visited by me. In the eastern area, under Darjiling, it is of little elevation, but rises to about 4000 feet, disappearing altogether near Dalingkote, but near Buxa the formation reappears, and is only some 2000 feet. Nothing is known of the older tertiary rocks up to the Aka and Dapha Hills, but here they attain again large proportion -4700 feet west of the Ranga to 6000 feet beyond that river. South of the Assam range, miocene strata, a distinct group, attain 1500 feet, but are poorly represented in places. At other points, as near the Sylhet bhils, they are absent. Near Jaintiapur they expand and reach an altitude of 3000 feet. Sonth of the Lukah River the whole mass gradually rises to 5cco feet near Asalu, and to 9890 at Japvo Peak, its culminating point in the Naga Hills; but these formations are, I believe, marine and estuarine. The great elevation of tertiary rocks here is the exact counterpart of what has taken place on the west, and both are on the great changes of strike in all the formations.

Within the mountains in the old rock basins-and these are analogous to the valleys of the Alps-are pliocene and postpliocene beds of great thickness, but of fresh-water origin; the remnants of which are to be seen in Kasbmir and scardo at intervals, along the valley of the Indus, and that large-now elevated-accumulation at the head of the Sutlej River in Hundes, first brought to notice by the labours of Captain (now General) R. Strachey. The remnants of these deposits in Kashmir and Scardo are found preserved in the more sheltered portions of the valley basins, untouched by the denuding action during the glacial period-the exponents presented to us of the enorixous denudation that went on during the post-pliocene times, of which the glacial period formed a part. The extent and displacement of the upper pliocene keds is in North Italy and here very similar. Often abutting horizontally against the mountains, they are in other places found tilted at considerable angles on the margin of their original extension. When we examine their contents, we find that the fauna of that time in Asia, as well as Europe, was more A frican in character, and genera now confined to that continent were abundant far to the north. The sluggish rivers and lakes of Sivalik times in Asia and of the corresponding period in Europe were the home of the hippopotamus, crocodiles, and tortoises, of which the common crocodile, the gavial or long-snouted species, and an emys have survived the many geological changes, and still inhabit the rivers and low grounds of India to-day. The fresh-water shells are still the same now as then. Many species of antelope lived in the neighbouring plains and uplands ; the elephant was there in the zenith of its existence, for no less than thirteen species have reen found fossil in Northern India; but it is impossible, in a short address, to enumerate the richness of this fauna, and the extreme interest that surrounds it.

Miocene of European Arca.-If we now turn to Europe to compare formations of similar age, Lombardy ard the valley of the Po, with the southern side of the Alps, present to us some- what similar physical features, A large area of about the size of the north-west Punjab, once a part of the miocene sea, is occupied by a remnant of rocks of that age, considerably elevated and tilted, but not to such an extent as those of the Himalayas. Near Turin these dip towards the mountains, and a very short examination shows the undoubted glacial character of some of the beds $;^{1}$ and, as the whole formation is marine, their large sharply angular material, much of which is jurassic limestone, was probably transported from the adjacent mountains by the agency of ice in a narrow sea. ${ }^{2}$ After the great crushing and alteration of the previous cutlines of the whole country another sea filled the basin of the Po, and pliocene deposits were laid down in a sinking area extending to the base of the mountains all round the new bay or gulf. Re elevation again set in, and with it, or soon after it, the advent of another, and the last, glacial period. But the bounds of the pliocene sea extended even farther than the base of the mountains. At the south end of the Lago d'Orta, well within the hills, sheltering under the isolated porphyry bill of Buccione, and 280 feet above the present lake (or 1500 feet above the sea), I bad the good fortune to discover this summer a patch of pliocene sands and clays, with marine shells in excellent preservation, which I am not aware has been noticed before. Sixty-four feet of the section is exposed, capped by moraine matter; its base was not seen, and the beds dip north. This remnant tells us a good deal. From where it rests there is a clear horizon to the north down the lake to the junction of its river with the Toce-unmistakable evidence that these beds must have extended far in this northern direction, and that long fjord-like arms of the sea stretched up as far as Domo d'Ossola on one side, and Bellinzona on the other. This marine bed is far above the level of the Lago Maggiore, but I may mention that I also found marine shells of pleistocene age II 2 feet above that lake near Arona, of which details cannot here be given.

Before the last great elevation of the Alpine chain the whole line of sea-coast, therefore, ran even bigh up the long deep valleys of Maggiore, Como, Garda, \&c., during the early plio. cene period; the mountains, then quite as high as now, enjoying a warm, moist climate, not a glacial one. Then came the gradual but uneven elevation of the whole area, including the miocene bills south of the Po, and lacustrine and estuary conditions prevailed over much of the plain country. The lapse of time was probably enormous, and as the land rose and the sea retired the climate gradually became cooler, and ushered in the glacial period. I d.) not think it would be an exaggeration to add another 5,coo fett to the Alpine peaks of that time, which would give them an altitude equal to the Zaskar range of the N.W. Himalaya of the present day. With the change and the increased volume of the mcuntain torrents, the destruction of the upraised marine pliocene beds commenced, and finally culminated in the extreme extension of the glaciers even into the plains; they scoured out almost completely the whole of these deposits, which then filled the great valleys and the country at the base of the mountains, to redistribute them again over the plain of the Po, and silt up what remained there of the old estuary or gulf towards the east. The denudation of this formation has been enormous along the base of the Alps, and only mere remnants are to be found. It is easily seen that their preservation is purely due to the accidental position in places where the great denuding force-viz. the advance of ice from the mountains-has been unable to touch them ; in other instances the early deposition of moraine matter upon them has acted like a shield, and prevented their entire destruction. Such examples are well seen near Ivrea, in the well-known section in the gorge of the Chieusella near Stombinella, and in the moraine near San ́́iovanni.

The scattered remnants of the pliocene formation south of the Alps, which took perhaps thousands of years to lay down, show well how soon a great formation, together with the preserved remains of the fauna living at the time, may be completely destroyed by subsequent denuding forces. Similar destruction must have occurred over and over again in past geological ages, and shows clearly how the scanty, broken record can be accounted for.

It is an established fact that the great valleys of the Alps and

${ }^{I}$ Refer to Gastaldi.

2 No trace has been observed of this glacial period in the miocene of India ; the most lofty portions of the chain had not then attained a greater elevation probably than 14,000 to 18,000 feet, and the outer axis lines far
less. However, in the tertiary beds (middle eocene?) of the Indus Valley below Leh such conditions are indicated by Lydekker. Memoirs of this address was sent India, 
Himalaya existed much in their present form during miocene times, and they may owe their excavation partly to the glacial action of that period, when these mountain slopes rose from the plain or margin of the ancient sea, far in front of the present line of slope, and were far higher than now. This idea particularly strikes one when looking at the ice-ground spurs that run out into the plain south of the Lago d'Orta. The general and local elevation and depression that took place in post-miocene times seem quite sufficient to account for the difference in the comparative levels of adjacent transverse valleys, or an elevation along the base of the chain, clearly indicated at Orta by the northeriy dip of the marine beds. It is reasonable to suppose that these movements were exerted in different degrees, at points all along this face of the Alps and within the same, and that the depression on the west has been less than on the east, so that the sea never extended far up the valley of Susa, and to a comparatively short distance up that of the Dora Baltea as compared with Maggiore, and the formation and excessive depth of this and similar lakes on the east is mainly due to this local depression and elevation. Depression has steadily continued in the delta of the Po as in the Ganges at Calcutta, for, at Venice, borings showed depression of land surface to an extent of 400 feet, and they did not reach the base of the formation. ${ }^{1}$

It is not improbable that during the earlier extension of the glaciers into the Maggiore basin, ${ }^{2}$ the sea still had access to it ${ }^{3}$ this would have greatly aided in the removal of the marine deposits, and then the deeper erosion of its bed near the Borromean Islands, so well put forward by Sir Andrew Ramsay. When we see the gigantic scouring which glaciers have effected in the hardest rocks on the sides and bottons of valleys, when we know for certain the enormous thickness they reached in the Alps, I do not doubt for a moment their capability of deepening a rock basin very considerably, or their power to move forward over and against slopes so low as $2^{\circ}$ to $3^{\circ}{ }^{\circ}{ }^{4}$

The earliest extreme extension of the glaciers was very great; we have evidence of it on the miocene hills near Turin, their surface being scattered over with transported material of great size, quite uncomnected with that other ancient period of glacial conditions during the miocene times mentioned above at a period too remote to further dwell upon here. Even now I feel that in dealing with this subject of the glaciation of the Alps, many of you may say that I am departing too much from geography. To this I would answer, glacial periods have been so intimately connected with the interchange of sea and land conditions, that where can the line be drawn in physical geography between the past and the present? It is as undefined as the line which separates species from genera.

An enormous interval of time must have elapsed, during which the cold was increasing and the glaciers advancing, and during which the rivers were distributing the consequent waste over the lower country, spreading out the more or less coarse material, sands, and clays, in broad fans in front of all the gr at gorges. Then came the first period of contraction of the glaciers, with many oscillations. Of this we have the evidence in the moraine; of Ivrea, Maggiore, \&c. Sections of these moraines show how they were piled the one uorn the other; how the building up of one line of lateral moraine was followed by its partial destruction on another forward movement of the ice, and the throwing down of another moraine upon it. Then were formed many of the smaller lakes, remains of which lie amid the debris thrown out into the plain. The glaciers retained this size for a very considerable time, and then apparently very rapidly retreated to far within the mountains, but still for another considerable period their dimensions were much larger than those of the present tine, into which they seem to have again rather rapidly shru $\}$.

Passing from the glacial action displayed in the outer Alps to that in the Himalaya, we find ample evidence of a period of great extension of such conditions, first in the erraties of the Attock plain and the Potwar, ${ }^{5}$ lying fifty to sixty miles from the gorge of the Indus at Torbela. We have again the fact that in

\section{Lyell, Prin. vol. i. p. 426 .}

With reference to the moraines of Ivrea, see pamphlet by I, uigi Bruno, I ter reni costituenti l'anfiteatro allo sbncco della Dora B.xltea.

3 The evidence is stronger as regards the Lago Garda.

4 There appears to be too great an advocacy, on the one hand, of ice action having done all the work of denudation; while, on the other, some writers consider this to have been extremely limited; it is the cumbination
of the two forces, I think, that effects so much and in so different a manner and degree.

5 A. Verchère, $J$. Asiat S. Bengal, 1867, pp. 113 II4; Theobald, Records of the Geological Socicty of India, $1877, \mathrm{p}$. 140 .
Baltistan, in the Indus valley, glaciers have twice descended far beyond their present limits, first down to Scardo itself, and then to some thirty miles below their present limits; while the glaciers of Nanga Purbet, towering above the Indus some 22,000 feet, must have descended into the bed of that river. Even allowing that the Potwar was not formerly a lacustrine basin, the great débacles from the mountains would have been sufficient to convey erratics fixed in ice to where they now lie. Cataclysms of the present time, caused by glacial obstructions, have raised the level of the Indus on the plain above Attock so much as eighty feet. When these glaciers were more than double their present size, gigantic floods must have often taken place, and formed boulder deposits high above present levels : such high-level gravels are to be seen not only in the Potwar, but also in the Naoshera Dhun on the Rajaurie Tawi River, containing boulders of nummulitic limestone and other rocks of the Pir Panjal on the north.

Again, north of the Chatadhar ridge, small glaciers, five to six miles in length, at one time filled the lateral valleys, descending towards the Chenab River to about 5,000 feet; and a very perfect moraine occurs in one valley. This ground must be very similar to that which has been described by Theobald as occurring in the adjacent Kangra district ${ }^{1}$ on the flanks of the Dhaoladhar ridge. Similar small glaciers existed, I believe, in the valleys of the Kajnay range, but I think that neither in this range nor in Budra wa did they ever descend into the main valleys; but the existence of these glaciers, together with the large snowbeds, had much to do with the formation of the high-level gravel. beds and fans through which the Jhelum and Chenab have since cut their way.

In fact, examples of the former extension of glaciers are widespread along the chain of the Himalayas from west to east. True moraines, and moraine-mounds, at 16,000 feet on the north side of the Baralasa Pass, attest the presence of glaciers on the elevated plain of Rukshu, where now the snow-line is over 20,000 feet. $^{2}$ Drew gives much valuable information regarding their former size. ${ }^{3}$ On the east, in Silkim, Sir Joseph Hooker ${ }^{4}$ has described moraines of great height (700 feet) and extent. Still further south and east, in the Naga Hills, a short period of greater cold is indicated by the moraine detritus under the loftiest portion of the Burrail range in latitude $25^{\circ} 30^{\prime} .^{6}$

Whatever may have been the length of the glacial period in the Alps-and it was very considerable-in the Himalayas it cannot have been so long and so general, although to a certain extent, contemporaneous.

In the Alps glaciation meets the eye on every side, and the mountains, up to a distinct level, owe their form and outline to its great and universal extension.

In the Himalayas it is difficult to trace polished surfaces or striæ markings, even in the neighbourho $\mathrm{d}$ of the largest glaciers that are now advancing in full activity. It has been suggested that obliteration is the result of more powerful denudating forces, but the conditions are not so very disimilar in the high Alps and high Himalaya as to warrant this ; and wherever the oldest strix marks occur in the Himalaya, they are situated near the bed of the valley. It may interest you if I give an illustration or two of the size of these present glaciers as compared with those of the Alps. The Baltoro glacier would extend, if placed in the Toce valley, from the Simplon to the margin of the Lago Magyiore; or take another illustration of its length, frum Mont Blanc to Châtillon in the Valle d'Aosta.

Although of such great length, these Himalayan glaciers could never lave reached the enormous thickness which the earlier Alpine glaciers attained. This may thus be accounted for: in the European area a generally low temperature prevailed down to the sea level, while in the Himalayan it was local, and confined to a higher level. It is evident that the snow-line has alteredhigher at one period, lower at another-down to recent times, denoting changes of the mean annual temperature, which are not yet fully understood, but have been attributed to very far distant distribution or alterations of land, sea, and the ocean currents.

Two periods of glacial extension are clearly defined, separated by a milder interval of climate: during the earlier glacial period

I Ibid. 1874 , p. 86 .

${ }^{2}$ North of the Karakoram, in that now arid country, great moraines are found in the valleys that descend into the Karakash, in the neighbourhood of the Sujet pass, 17,600 feet. (Harold, Godwin-Austen in Epit.)

3 The Jummoo and Kashmir Territories.

4 Himalayan Journals, vol. i. p. $22 \mathrm{x}$.

5 The equivalents, although very small, of such moraines are to be seen in the Alps on the Simplon jutting out into the valley

6 Godwin-Austen, $J$. A.S. B. 1875, p. 209. 
the Indus valley was filled with those extensive lacustrine and fluviatile deposits, mixed with large angular debris, such as we see at Scardo, which may be coeval with the extreme extension of the Alpine erratics so far as the miocene hills south of Turin.

The second period followed after a long interval of denudation of the same beds, and would correspond with the last extension of the great moraines of Ivrea, Maggiore, Como, \&c., followed by a final retreat to nearly present smaller dimensions. Nowhere on the south of the Himalaya do we find valleys presenting any features similar to those of the Southern Alps, particulariy on the Italian lakes, which are, I believe, the result in the first place of marine denudation, succeeded by that of depression, and finally powerful ice-action. On the south face of the Khasi and Jaintia Hill-, however, which are orographically connected with the peninsula of India-the conditions altogether different-ve find long stretches of water of considerable breadth and depth extending within the hills, and not unlike in miniature the Itaiian lakes. These valleys, worn out of the sandstone and limestone rock, have been formed here, I think, to some extent by the aid of marine action, and the subsequent depression along this line of hills, also marked here, as in the Western Bhutan Doars, by the absence of beds newer than the nummulitic.

This attempt to bring before you some of the great changes in the geography of Europe and Asia must now be brought to an end. It is a subject of vast time, of absorbing interest. I am only sorry it is not in more able hands than mine to treat it in the manner it deserves, and in better and more eloquent language ; but it is a talent given to but few men (sometimes to a Lyell or a Darwin) to explain clearly and in an interesting form the great and gradual changes the surface of the earth has passed through. The tudy of those changes must create in our minds humble admiration of the great Creator's sublime work, and it is in such a spirit that I now submit for your consideration the subject of this address.

\section{SECTION G}

\section{MECHANICAL SCIENCE}

OPEning ADdress by James Brunlees, F.R.S.E., F.G.S., Pres. Inst.C.E., President of the SeCtion.

THE British Association for the Advancement of Science admits to its annu-l gathering women as well as men; and I venture to think it does so wisely. Women now take their place regularly in the ranks of several scientific professions; and though they have not shown any desire to enter that to which I belong, there has recently been an example of their capability in that direction which is noteworthy. It has been publicly stated that Col. Roebling, the distinguished engineer of the Brooklyn suspension bridge, which is one of the most remarkable works of the age, was as isted during a long illness in carrying out his work by the talent, industry, and energy of his wife, who acquired theoretical and practical knowledge enough to aid in seeing that her husbasd's design was properly carried out. I think this example is not unworthy of mention here, as honourable to the individual woman, to the energetic nation to which she belongs, and to the better half of the human race.

The previous meetings of the British Association have been held in places possessing very varied characteristics ; but in none in which the pursuits of science could be undertaken under more pleas ng circumstances than in Southport, with which I have been acquainted for a go d many years.

It is customary for the President of each Section to begin the Session by giving an introductory address. I propose, with your kind indul gence, to offer some brief remarks, as far as possible free from technical language, on a subject which is familiar to my own mind, and within my own experience, during a period now approaching half a century, that is: The growth of mechanical appliances for the construction and working of railways and docks.

The railway of the present day is in principle what it was at the outset; but it differs in detail from the original railway as much as, or more than, the skewer which fastened the dresses of the ladies of Elizabeth's time from the pin of the present day, or the carpets of this era from the rush-strewn floors of that. The progress has been gradual, but not slow. From the opening of the first railway to the present date is only a period of about sixty years, and in that short time Great Britain and Ireland, the continent of Europe, America, North and South, India, Australia, and Africa, have been pretty well supplied with railway lines, more and more perfect in construction, and in a degree more or less suitable to the needs of their populations.

About thirty years ago, when the traffic on railways had been very largely developed, the parts of the permanent way which had at first been thought likely to be the most enduring, the rails themselves, were found to be more rapidly worn away than was expected. Efforts were made to harden the surface of the rails, and a plan was introduced by Mr. Dodds for this purpose. It was extensively used where rails were subject to special wear and tear, at points and crossings. The conversion was easily effected : it cost only about fourteen shillin ss to a pound a ton, and it was estimated that it doubled the durability of the rails. If they were turned, of course it increased their durability three times.

The plating of rails with a steel surface was probably begun about 1854 . It was not till about eight or ten years later that rails were made entirely of steel.

In May, 1862, steel rails were laid down experimentally at Chalk Farm Bridge "side by side with two ordinary iron rails, and after outlasting sixteen faces of the iron rails they were taken out in August 1865, and the one face only which had been exposed during a period of more than three years to the enormous traffic, amounting to something like 9,550,000 engines, trucks, \&c., and $95,577,240$ tons, although worn to the extent of a little more than a quarter of an inch," even then appeared capable of enduring a good deal more work. Steel rails, however, were dear at that period, costing about double (12l. ros. per ton) as much as iron rails; therefore, although their advantages were manife $t$, they could not all at once replace iron. In $1866, \mathrm{Mr}$. Webb, the locomotive engineer of the Lnndon and NorthWestern Railway, said they had in use 3000 tons of steel-headed rails and about fifty miles of steel rails; and Mr. Harrison, of the Norih-Eastern, said he had just contracted for 500 tons. Now, owing to improvements in the manufacture of steel rails, they can be produced as easily and as cheaply as iron rails. It was observed in 1876 that if, in order fully to realise the effect of the enduring quality of steel rails, you take a given section of the busiest portion of one of our leading railways, over which upwards of $7,000,000$ tons of live and dead weight pass annually, you would find that the life of a steel rail on that portion of the line would be forty-two years if the traffic remained the same. This would reduce the cost of maintaining the permanent way of railways from $2 \mathrm{IO} l$. to $\mathrm{I0} l$. per mile. When you consider that such a saving on a system of 500 miles, which at $25,000 l$, a mile costs twelve and a half millions, is $52,000 \%$ year, or about a half per cent. of the cost of the railway, you will see that, besides some increase of dividend to shareholders, no inconsiderable sum may be, and has been, devoted by the railway systems of Great Britain to the comfort of travellers out of the saving effected by the introduction of steel rails.

You are aware that railways are worked by the aid of an elaborate system of signals, by which those in charge of a train are required to be guided in regard to its movements. The author then gave a history of signals, bringing his account down to the present day.

The subject of brake power is one to which very great attention has been given both in this country and abroad; and certainly, next to the condition of the permanent way and the efficiency of the signalling apparatus, perhaps nothing in connection with railways is of greater importance. Many lives and much property are hourly dependent in a greater or less degree on the power and efficient state and immediate action of brakes. It has been found that most of the collisions which have occurred might have been prevented had those in charge of trains possessed the power of stopping them within a few hundred yards. The higher the speed and the heavier the train, the greater the necessity for a powerful and simple brake, capable of being applied throughout the train in the shortest possible time.

All recent efforts for the improvement of brakes appear to have been devoted to making the action of the brakes automatic, and to increasing the rapidity with which they can be applied.

I do not intend to enter into the controversy respecting the best system in use for obtaining these results. There are several systems by which they are attained more or less effectively; and whereas trains which thirty years ago weighed on the average thirty tons, with engines of the same weisht, running at thirty. five miles an hour, could scarcely be brought to a stand in a distance of about 800 or 1000 yards, now trains of twice or three times that weight, and running at a much higher speed, can be brought to absolute rest in twenty or thirty seconds, and within a distance of from 300 to 400 yards. 
When railways were first made, the locomotive was a very imperfect machine, which could only travel economically on roads almost level and straight. As there are no level plains of great length in this country, and as reducing the natural surface of the country to a fair level is both tedious and costly, considerable detours were made to avoid steep gradients or their alternative, long tunnels, deep cuttings, and high embankments. In some cases where a very steep gradient could not be avoided, a stationary engine and rope traction were adopted. The great improvements in the locomotive gradually led to the almost entire abandonment of rope traction in this country; and gradients which it would have been impossible for the earlier engines to surmount with a load equal to their own weight are now ascended with ease with heavy trains at moderate speeds. Abroad, however, great natural difficulties and a limited capital were not infrequently concurrent conditions which offered to the engineer troubl-some problems for solution. In some districts the locomotive conld not do the required work, and other mean have had to be resorted to. The plans adopted for overcoming the difficulty presented by the sudden elevation of the surface over which a railway must pass may be typified by the wire-rope system, as employed by myself on the St. Panlo Railway of Brazil, and by the central rail system of Mr. Fell, first employed on the Mont Cenis Railway, and since on steep inclines in New Zealand.

The central rail system was designed by Mr. Fell, and first carried out practically in the railway maje over Mont Cenis, under my direction, before the opening of the great tunnel. The peculiarity of the system lies in the use of a deep rail laid on its side between the two ordinary rails; the centre rail is gripped by horizontal wheels, put in motion by the locomotive, the adhesion of which to the centre rail gives the locomotive the force neces iary to draw up steep inclines, not only its own weiglit, but a considerable supplementary load. This is probably the most economical mode of working very steep gradients under ordinary circumstances, and it has been found to answer very well wherever it has been efficiently carried out.

In the construction of railw sys and docks one of the most expensive and tedious operations is the excavation of the soil. In England the cutting of numerous canals had trained a large body of men to special fitness for the execution of such work, which they performed with a manual dexterity and amount of muscular power which have made the British navvy a special force in the execution of great public works. Where labour was comparatively scarce and inefficient, as, for instance, in America, efforts were made at an early period to supplement, and, if possible, supersede, such manual labour by mechanical contrivances. In 1845 a mechanical excavator, after an American model, was used on the Eastern Counties Railway with a certain amount of success. This machine delivered as much as 1oo cubic yards an hour at a cost which did not exceed fifty shillings a day. In principle, and generally in detail, it is very much the same as the excavator which is commonly known as the "steamnavvy" at the present day. The machine was locomotive, and had three other kinds of motion-first, thrusting the scoupor shovel into the earth; second, lifting the scoop when filled; and third, turning round on its centre to deposit the earth in the waggons. The use of small locomotives for tipping the soil for embankments has relieved the workmen of one very laborious and sometimes dangerous occupation, and in a corresponding degree has diminished the cost of construction.

One of the most important operations in connection with shipping is the repairing, cleaning, and painting of ships. For this purpose graving docks, from which the water was removed after the vessel had entered, were and continue to be mostly employed. But during the lifting of the tubes of the Britannia Bridge into place with what were then called hydraulic presse:, it occurred to Mr. Edwin Clark that similar means might be used to lift a vessel out of the water and place it in a position to be dealt with similarly to a constrution on dry land. Floatiny docks consisting of pontoons which lifted the vessel out of the water have been used in this country, and more extensively in America, for this purpose : and at San Francisco and Philadelphia a dock was constructed of pontoons in sections called "camels," any number of which might be used according to the size of the vessel to be docked. Mr. Clark's plan is quite different from these. His hydraulic dock consists of a number of columns arranged in two parallel rows, in which columns are placed the hydraulic lifting power. Between these two rows of columns extends a frame or cradle, over which the ship is drawn in the water. When the ship is in position the hydraulic lifts are set to work, and they raise the cradle first to the bxitom of the ship, which, being properly secured, is then lifted with the cradle clear of the water. There is no difficulty whatever in the management of this form of dock, and it has been perfectly successful: its chief recommendation being that any area of shallow water can be made available for docking large vesiels, and that it is especially valuable in tideless seas.

Among the many mechanical appliances for saving labour on railways and docks, the machinery for shipping coal is remark. able : the bulk, weight, and low price of coal render every item of saving in transport relatively important. It is commercially important also that the coal in the different stages of transport from the pit to the distant consumer should be broken as little as possible, and a good deal of attention has been given to contrivances to secure these ends.

A great variety of hydraulic machinery has been designed by Sir William Armstrong for coal loading, and it is largely em. ployed at Newport Docks and elsewhere.

Many different kinds of labour-saving machinery for dock and railway work in loading and unloading have been invented during the last fifty years, and have had a most imp rrtant influence on the development of railway and steamship transport.

Hydraulic machinery has also been largely employed for opening and closing dock gates and sluices, and for warping ships through the locks.

A large dock is in course of construction at Hull, by Mr. Abemethy, called the Alexandra Dock, where almost every kind of machinery which can be used in work of that nature is being used by the contractors, Mesirs. Lucas and Aird, to expedite the work. Two of Priestman's steam grabs are employed, each capable of filling about 390 cubic yards a day, and are found very useful ii opening out work for the steam navvies, six of which are employed, each being capable of fillins 600 cubic yards a day. There are a $n$ mber of steam cranes, steam piledriving machines, and steam jiggers at work. But, be-ides those moved by steam power, hydraulic power has here for the first time been applied to machinery for the construction of works. An hydraulic crane puts the stonework of the dock walls in place; an hydraulic jigger raises the barrow-loads of soil from the bottom of the dock to the wall where it is shot to the back for filling. One of the six navvies is moved by hydraulic power; and there is an hydraulic pile-driving machine. The hydraulic machinery is found to work at least as quickly, as easily, and as economically as steam machinery, and it works almost with. out noive, and quite without smoke. The trial of hydraulic machinery for these purpo es has been quite successful, and where circumstances permit it will no doubt be used extensively in works of construction in future. For dock work much of the hydraulic machinery can be used permanently in the ordinary operations of loading and unloading, so that the loss by sale of such expensive plant, which a contractor has to tal. e into account when making his tender, will be avoided, as it can be turned over to the dock company, with a reasonable deduction for wear and terr, at the end of the work. There are 2800 inen employed at this dock; and the work is carried on at night by the aid of the electric light. The mechanical navvies and grabs do the work of about 400 additional men.

The working $f$ railways by electricity has not advanced further than to justify merely a brief reference $t_{1}$, it in this paper as among the possibilities, perhaps the probabilities, of the not distant future. A line of a mile and a half of tramway has been working successfully at Berlin for over two years without hitch or ac ident of any kind. A line of narrow gance railway is constructed from Portrush, the terminus of the Belfast and Northern Counties Railway, to Bush Mills, in the Bush Valley, a distance of six miles, which is now partially worked by electricity, and is to be wholly so worked as sjon as the neces ary plant is completer. As the generating power is that of the abundant streams of the neighbourhood, it will be economical; and if success should crown this practical experiment, it may lead to important results in regard to the employment of electricity ander similar circumstances as a locomotive power.

I have now passed rapidly in review some of the more s'riking mechanical improvements in the construction and working of railways and docks which have taken place chiefly within my own experience. Each of them has had an influence, important if unnoticed, in promoting the growth of our rililway and dock systems. Precisely how far any single appliance has contributed to create these magnificent systems, of wh ch this country may with just reason be proud, it would he difficult to say; and it would be as difficult to say which of them 
could be dispensed with without injury to the rest. They may be laid aside in course of time, one by one, as mechanical ingenuity devises new and better plans to take their place, and to meet the new and larger wants of other generations. But as the present age looks back with respect and veneration to the creation of those monuments of engineering science of which little more than ruins or even historic records remain, so will the generations which succeed us look on these, our works, as worthy, and as having contributed in no small degree to the greater and more general civilisation to which we hope those who follow us may attain.

\section{UNIVERSITY AND EDUCATIUNAL INTELLIGENCE}

CAMBRIDGE.-The following courses of lectures and practical work have been announced for the present term by the Special Board for Physics and Chemistry :-

Chemistry.-Prof. Liveing, General Principles; Prof. Dewar, Physical Chemistry, advanced ; Mr. Main (St. John's), Organic, elementary; Mr. Pattison Muir (Caius), Organic, advanced; Metals, elementary ; Mr. Scott (Univ. Lab.), Physical, elementary ; Mr. Lewis (Downing), catechetical.

Practical Chemistry.-Prof. Liveing, Spectroscopic Analysis; Mr. Sell and Mr. Fenton, Quantitative Analysis ; Mr. Robinson, Analysis of Water and Food. The University, St. John's, Caius, and Sidney College Laboratories will be ofen for practical work.

Physics.-Lord Rayleigh, Current Electricity and its Practical Applications ; Mr. Trotter (Trinity), Electricity and Magnetism, elementary; Mr. Atkinson (Trinity Hall), Heat and Hydrostatics, elementary; Mr. Shaw (Emmanuel), Physics, elementary and advanced. Practical work at the Cavendish Laboratory, with advanced demonstrations.

Mineralogy and Crystallography.-Prof. Lewis, with practical demonstrations.

Mechanism.-Prof. Stuart, with practical work at the mechanical workshop.

The Special Board for Biology and Geology have published the following list of lectures for this term :-

Physiology.--Prof. Foster, elementary; Mr. Lea (Caius), Chemical Physiology, advanced; Mr. Langley, Physiology, advanced; Mr. Hill (Downing), second M.B. class.

Zoology and Comparative Anatomy, and Animal Morphology. -Prof, Newton will lecture on Evolution in the Animal King. dom; Mr. Sedgwick, Practical Morphology, elementary and advanced; Dr. Hans Gadow, Morphology of Ichthyopsida, advanced.

Botany.-Dr. Vines (Christ's College), General Elementary Course, and Advanced Physiology.

Geology.-Prof. Hughes, Geology of France, Switzerland, and Italy; and Pleistocene Geology, with special reference to Prehistoric Archæology; Dr. R. D. Roberts (Clare College), Physiography and Class Work; Palæontology and Petrology by a Demonstrator : and Field Lectures, by special notice.

\section{SOCIETIES AND ACADEMIES SYDNEY}

Royal Society of New South Wales, June 6.-Charles More, F.L.S., vice-president, in the chair.-Two new members were elected, and 156 donations received. The following paper by Mr. Peter Beveridge was read:-On the aborigines inhabiting the great lacustrine and riverine depression of the Lower Murray, Lower Murrumbidgee, Lower Lachlan, and Lower Darling.

\section{PARIS}

Academy of Sciences, September 24.-M. Blanchard, president, in the chair.-The death was announced of M. Joseph A. F. Plateau, Correspondent of the Section of Physics, who died at Ghent on September I5. A summary of the scientific work of the illustrious savant was given by M. Faye. - The death was also reported of M. Thuillier, a member of the Egyptian Cholera Commission, who fell a victim to the disease at Alexandria on September 19. - Note on solar spectra, with the results obtained with the mineral salt refringent apparatus described in the Comptes Rendus of September 4, 1882.-Remarks by M. Gaudry on some specimens of extinct Siberian mammoths ob- tained by him during a recent visit to Kussia, and now sub mitted to the Academy. The specimens consisted of some hair mixed with wool and a piece of skin taken from the mammoth brought to St. Petersburg by M. de Maydell in I87 I. -On a new and more general case of the problem of the resistance of an elastic rod, and one of its applications, by $\mathrm{M}$. Maurice Lévy. - On the action of the turbine used to set in motion the electric generator at Vozille-Gare, by M. Marcel Deprez.-Additional note on the probable epochs of earthquakes, by M. J. Delauney. The author replies to the objections recently urged against his theory by M. Faye, and formulates the following law :-Most cosmic and terrestrial meteorological phenomena, and especially the great seismic disturbances, seem to occur when the great planets pass through certain longitudes, notably those of $135^{\circ}$ and $265^{\circ}$, or thereabouts. -Observations on the small planets $159,199,218$, and on the Pons-Brooks Comet, made at the Paris Observatory (equatorial of the West Tower), by M. G. Bigourdan.-Observations on the planet II 3 Amalthra, by M. Perigaud.-On the induction due to the variation in intensity of the electric current in a plane circuit and in a cylindrical solenoid. Two laws analogous to those of Biot and Savart, by M. Quet. - Researches on the dispersion of light, by M. C. E. de Klercker.-On the distribution of the potential in liquid masses of determined form, by $M$. A. Chervet. Two cases are dealt with: (a) that of a rectangular plate of indefinite length; (b) that of a liquid mass limited by two vertical parallel planes. - Terrestrial magnetism; solution of the problem of the determination of the magnetic meridian by the compass itself on board iron ships, by M. E. Bisson.-On the composition of the substance known as gelatino-peptone, which is obtained by the action of the gastric juice on gelatine, by $\mathrm{M}$. P. Tatarinoff.-Fresh observations on the tubercules and root: of Phylloglossum Drummondii (Kunze), by M. C. Eg. Bertrand. -On the influence of external pressure on the absorption of water by roots, memoir by M. J. Vesque.

\section{CONTENTS}

PAGE

Physiological Cruelty. By George J. Romanes,

F.R.S.

Our Book Shelf :-

"The Transactions of the New Zealand Institute" . 538

Munro's "Electricity and its Uses". . . . . 538

Letters to the Editor:-

Professor Henrici's Address at Southport.-Prof. O.

Henrici, F.R.S. R . - • • . . 539

The New Comet.-J. Rand Capron . . . 539

The Genus "Simotes" of Snakes.-Henry 0 .

Forbes . . . . . . . . 539

Floating Pumice.-Henry O. Forbes . . . 539

"Elevation and Subsidence."-Charles Ricketts;

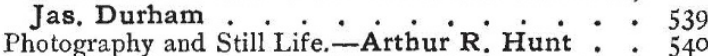

Animal Intelligence.-Dr. Henry MacCormac . . 54I

Meteor.-.C. Fortescue .. . . . . . . 54I

A Remarkable Rainbow.-i. C. . . . . . . . . $54 \mathrm{I}$

Professor Cayley. - R. T. . . . . . . . . . $54 \mathrm{I}$

The Nordenskjöld Greenland Expedition . . . . $54 \mathrm{I}$

The Present Condition of Fish Cuiture. By R.

Edward Earll . . . . . . . . . . . . 542

Notes . . . . . . . . . . . . . . 544

Our Astronomical Column :-

The Reappearance of Pons' Comet of 1812 . . . . 546

A New Comet . . . . . . . . . . . . 546

M. Trouvelot's Red Star . . . . . . . . 546

Geographical Notes . . . . . . . . . . 546

The British Association :-

Reports

547

Section B-Chemical Science. . . . . . 550

Section $\mathrm{E}-$ Geography-Opening Address by Lieut. Colonel H. H. Godwin-Austen, F.R.S.,

F.G.S., F.R.G.S , \&c., President of the Section

Section G-Mechanical Science-Opening Address by

James Brunlees, F.R.S.E., F.G.S., Pres.

Inst. C. E., President of the Section . . . . . 558

University and Educational Intelligence . . . . 560

Societies and Academies . . . . . . . 560 